\title{
PENGARUH ALOKASI ANGGARAN INFRASTRUKTUR JALAN TERHADAP KUALITAS INFRASTRUKTUR JALAN DAN PERTUMBUHAN EKONOMI DAERAH KABUPATEN CIANJUR DAN LIMA KABUPATEN DI JAWA BARAT
}

\author{
ILHAM \\ Jurusan Teknik Sipl Fakultas Teknik \\ Universitas Suryakancana Cianjur \\ ilhamipong@yahoo.co.id
}

\begin{abstract}
ABSTRAK
Kabupaten Cianjur pada tahun 2015 memiliki laju pertumbuhan ekonomi sebesar 5,47\% dan pada tahun 2016 pertumbuhannya mencapai 6,39\%. Walaupun laju pertumbuhan ekonomi Kabupaten Cianjur relatif cukup tinggi diantara kabupaten se Jawa Barat, namun besarnya PDRB Kabupaten Cianjur tahun 2016 berdasarkan harga konstan tahun 2010 sebesar Rp. 26,98 triliun tergolong masih rendah, dimana PDRB rata-rata kabupaten di Provinsi Jawa Barat adalah sebesar Rp. 54,29 triliun. Sehingga hal tersebut masih memerlukan peningkatan dari yang telah dicapai saat ini.

Selain daripada itu infrastruktur jalan Kabupaten Cianjur kondisi mantapnya pada tahun 2016 masih sangat rendah, yaitu sebesar 37,87\%, bahkan terendah diantara 14 kabupaten di Jawa Barat. Kualitas jalan yang rendah ini kurang mendukung terhadap pertumbuhan ekonomi Kabupaten Cianjur.
\end{abstract}

Hasil analisis efisiensi korelasi kualitas jalan (kondisi mantap) terhadap pertumbuhan ekonomi tahun 2015 dengan menggunakan metode Data Envelopment Analysis (DEA) terhadap Kabupaten Cianjur dan 5 kabupaten lainnya di Jawa Barat, menunjukkan kualitas jalan yang dicapai 6 kabupaten tersebut pada tahun 2015 belum mencapai skala efisiensi untuk mendukung pertumbuhan ekonomi setiap kabupaten. Inefisiensi pada Kabupaten Cianjur terjadi karena rendahnya kualitas jaringan jalan yang menjadi akses menuju ke pusat-pusat produksi pertanian, dimana sektor pertanian merupakan penyumbang terbesar PDRB Kabupaten Cianjur.

Dari hasil analisis efisiensi alokasi anggaran infrastruktur jalan terhadap kualitas jalan dengan menggunakan metode DEA, menunjukkan bahwa alokasi anggaran Kabupaten Cianjur, Kabupaten Bandung, Kabupaten Bandung Barat, dan Kabupaten Sumedang belum mencapai skala efisiensi.

Berdasarkan hasil evaluasi terhadap capaian kondisi mantap jalan Kabupaten Cianjur, yang diperoleh dari hasil pelaksanaan program kegiatan penanganan jalan yang telah dilaksanakan pada tahun 2015 dan 2016, dapat diketahui inefisiensi alokasi anggaran infrastruktur jalan terjadi karena tidak seluruh ruas jalan Kabupaten Cianjur dalam kondisi mantap mendapat alokasi anggaran pemeliharaan jalan. Akibatnya terjadi penurunan kondisi sebagian dari ruas jalan mantap menjadi rusak. Pada tahun 2015 penurunan kondisi jalan mantap menjadi rusak sebesar 3,13\% dan pada tahun 2016 sebesar 1,28\%.

Untuk dapat mendukung pertumbuhan ekonomi Kabupaten Cianjur dari sektor lapangan usaha pertanian dan kehutanan, alokasi anggaran penanganan jalan agar diprioritaskan pada ruas-ruas jalan yang merupakan akses menuju pusat-pusat produksi pertanian yang kondisinya rusak, mengingat sektor tersebut merupakan penyumbang terbesar PDRB Kabupaten Cianjur. Selain daripada itu untuk meningkatkan kondisi jalan mantap dan efisiensi alokasi anggaran infrastruktur jalan, Pemerintah Kabupaten Cianjur sebaiknya lebih memprioritaskan alokasi anggaran untuk kegiatan pemeliharaan jalan daripada jenis penanganan jalan lainnya.

Kata kunci : PDRB, kualitas jalan, kondisi mantap, Data Envelopment Analysis, efisiensi. 


\section{BAB I PENDAHULUAN}

\section{1 Latar Belakang}

Kabupaten Cianjur memiliki luas wilayah $361.434,98 \mathrm{Ha}\left(3.614,35 \mathrm{~km}^{2}\right)$ dengan jumlah penduduk 2.243.904 jiwa pada tahun 2015. Secara administratif, Kabupaten Cianjur terdiri dalam 32 Kecamatan. Berada di tengah Provinsi Jawa Barat, dengan jarak sekitar 65 $\mathrm{km}$ dari Ibu Kota Provinsi Jawa Barat (Bandung) dan $120 \mathrm{~km}$ dari Ibu Kota Negara (Jakarta).

Berdasarkan data dari Badan Pusat Statistik Kabupaten Cianjur, nilai Produk Domestik Regional Bruto (PDRB) Kabupaten Cianjur tahun 2016 atas dasar harga konstan tahun 2010 sebesar Rp. 26,98 trillun dengan laju pertumbuhan sebesar $6,43 \%$ dan pada tahun 2017 sebesar Rp. 28,52 triliun dengan laju pertumbuhaN SEBESAR 5,72\%. Sektor penyumbang terbesar PDRB tahun 2016 tersebut adalah sektor Pertanian, Kehutanan, dan Perikanan, yaitu sebesar Rp. 8,44 triliun $(33,77 \%)$. Hal ini dapat dimengerti karena Kabupaten Cianjur merupakan daerah agraris yang sudah sejak lama dikenal sebagai salah satu penghasil padi terbesar di Jawa Barat. Padi yang dihasilkan para petani di Kabupaten Cianjur sangat dikenal tidak hanya di wilayah Jawa Barat saja, tetapi sudah diakui oleh masyarakat Indonesia pada umumnya. Jenis padi yang sangat terkenal yang dihasilkan oleh petani Kabupaten Cianjur adalah jenis beras Pandan Wangi (Aromatic Rice). Beras Pandan Wangi merupakan salah satu jenis beras kualitas premium dan komoditas unggulan Kabupaten Cianjur. Selain beras komoditas sektor pertanian unggulan lainnya adalah kacang tanah, kedelai, jagung, ubi kayu dan ubi jalar.

Walaupun laju pertumbuhan ekonomi Kabupaten Cianjur relatif cukup tinggi diantara kabupaten di Jawa Barat, namun besarnya nilai PDRB Kabupaten Cianjur pada tahun 2016 menempati peringkat ke-10 dari 17 kabupaten di Provinsi Jawa Barat, sebagaimana terlihat pada Gambar 1 berikut.

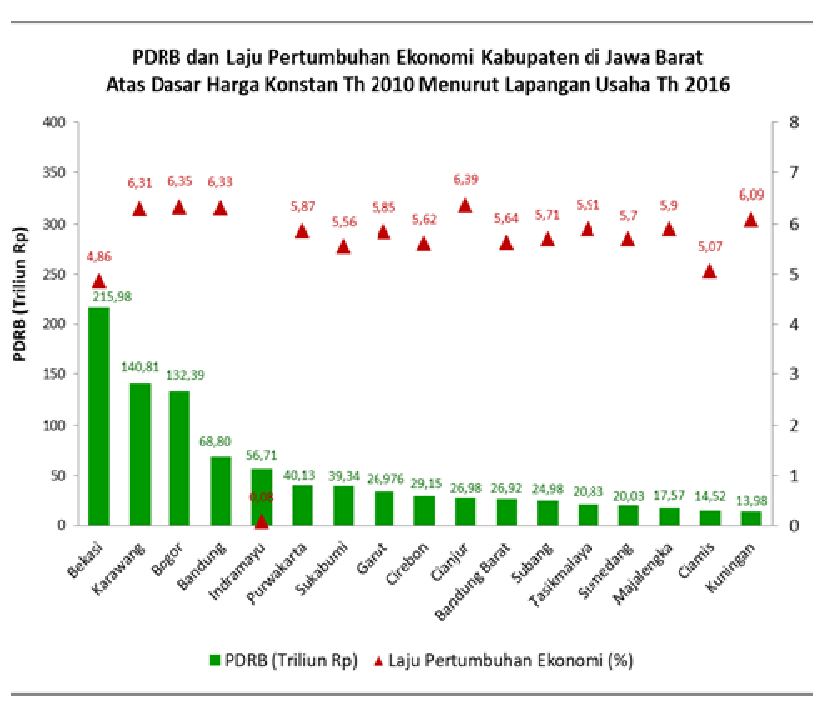

Sumber : Diolah dari Data BPS Jawa Barat Th 2017

Gambar 1. PDRB dan LPE Kabupaten di Jawa Barat Atas Dasar Harga Konstan Th 2010 Menurut Lapangan Usaha Th 2016

Sebagaimana diketahui bahwa pertumbuhan ekonomi suatu daerah sangat dipengaruhi oleh kondisi infrastrukturnya. Salah satu infrastruktur pendukung kegiatan ekonomi daerah tersebut adalah infrastruktur jalan. Hal tersebut sebagaimana dijelaskan dalam Undang-undang Nomor 38 Tahun 2004 tentang Jalan, bahwa peran infrastruktur jalan adalah sebagai bagian dari prasarana transportasi yang mempunyai peran penting dalam bidang ekonomi, sosial budaya, lingkungan hidup, politik, pertahanan dan keamanan. Dengan demikian kondisi kualitas jaringan jalan di daerah kabupaten sangat mempengaruhi pertumbuhan ekonomi di kabupaten tersebut.

Untuk mengetahui kondisi jalan kabupaten dalam memberikan dukungan terhadap kegiatan perekonomian di wilayah kabupaten Jawa Barat, Tabel 1 berikut ini memperlihatkan data panjang jaringan jalan kabupaten dan kondisi jalan di 14 kabupaten di Jawa Barat pada tahun 2016. 
Tabel 1. Panjang Jaringan dan Kondisi Jalan Kabupaten di Jawa Barat Tahun 2016

\begin{tabular}{|c|c|c|c|c|c|c|}
\hline \multirow[b]{2}{*}{ No. } & \multirow[b]{2}{*}{ Kabupaten } & \multirow{2}{*}{$\begin{array}{c}\text { Panjang } \\
\text { Jalan } \\
(\mathbf{k m})\end{array}$} & \multicolumn{3}{|c|}{ Kondisi Jalan } & \multirow{2}{*}{$\begin{array}{c}\text { Persentas } \\
\text { Jalan } \\
\text { Mantap }\end{array}$} \\
\hline & & & $\begin{array}{l}\text { Baik } \\
(\mathbf{k m})\end{array}$ & $\begin{array}{c}\text { Sedang } \\
(\mathbf{k m})\end{array}$ & $\begin{array}{c}\text { Rusak } \\
\text { (km) }\end{array}$ & \\
\hline 1 & Bogor & $1.698,720$ & $1.262,914$ & 154,638 & 281,168 & $83,45 \%$ \\
\hline 2 & Cianjur & $1.301,697$ & 324,763 & 168,168 & 808,766 & $37,87 \%$ \\
\hline 3 & Sukabumi & $1.184,845$ & 226,400 & 379,200 & 579.271 & $51,11 \%$ \\
\hline 4 & Bandung & $1.123,773$ & 588,548 & 248,859 & 286,337 & $74,52 \%$ \\
\hline 5 & Subang & $1.054,500$ & 502,310 & 401,930 & 150,266 & $85,75 \%$ \\
\hline 6 & Bekasi & 946,997 & 789,961 & 21,661 & 135,421 & $85,70 \%$ \\
\hline 7 & Ciamis & 848,290 & 381,670 & 153,530 & 313,104 & $63,09 \%$ \\
\hline 8 & Kuningan & 828,440 & 518,450 & 192,550 & 117,473 & $85,82 \%$ \\
\hline 9 & Indramayu & 809,870 & 566,560 & 133,150 & 110,142 & $86,40 \%$ \\
\hline 10 & Sumedang & 774,606 & 446,251 & 138,328 & 190,011 & $75,47 \%$ \\
\hline 11 & Purwakarta & 728,924 & 497,868 & 139,549 & 91,480 & $87,45 \%$ \\
\hline 12 & Majalengka & 718,315 & 652,975 & 20,410 & 44,895 & $93,75 \%$ \\
\hline 13 & $\begin{array}{l}\text { Bandung } \\
\text { Barat }\end{array}$ & 553,650 & 213,670 & 127,660 & 212,325 & $61,65 \%$ \\
\hline 14 & Garut & 362,920 & 222,650 & 106,240 & 34,042 & $90,62 \%$ \\
\hline
\end{tabular}

Sumber : Kabupaten Dalam Angka Th 2017

Dari Tabel 1 tersebut di atas terlihat Kabupaten Cianjur memiliki panjang jalan kabupaten terpanjang ke-2 di Jawa Barat setelah Kabupaten Bogor, namun pada tahun 2016 kondisi mantap jalan Kabupaten Cianjur merupakan yang terendah dari 14 kabupaten di Jawa Barat, yaitu sebesar 37,87\%, sementara rata-rata kondisi mantap jalan kabupaten di Jawa Barat pada umumnya berada di atas $60 \%$.

Untuk menjaga kualitas kondisi jalan agar dapat melayani kebutuhan pergerakan barang dan jasa yang mendukung kegiatan perekonomian daerah, pemerintah daerah kabupaten setiap tahun mengalokasikan anggaran untuk menjaga kualitas kondisi jalan dengan jumlah alokasi anggaran bervariasi sesuai dengan panjang dan kondisi jalan di masing-masing daerah kabupaten. Tabel 2 berikut ini memperlihatkan perbandingan alokasi anggaran penanganan jalan kabupaten dan kualitas kondisi jalan mantap serta pertumbuhan ekonomi 6 kabupaten di Jawa Barat pada tahun 2015.
Tabel 2. Alokasi Anggaran Penanganan Jalan Kabupaten, Kualitas Jalan Dan Pertumbuhan Ekonomi 6 Kabupaten di Jawa Barat Tahun 2015

\begin{tabular}{|clccc}
\hline No. & KABUPATEN & $\begin{array}{c}\text { ANGGARAN } \\
\text { INFASTRUKTUR } \\
\text { JALAN }\end{array}$ & $\begin{array}{c}\text { KUALITAS } \\
\text { JALAN } \\
\text { (KONDISI } \\
\text { MANTAP) }\end{array}$ & $\begin{array}{c}\text { PERTUMBUHAN } \\
\text { EKONOMI }\end{array}$ \\
\hline 1 & Cianjur & Rp. 99 miliar & $35,88 \%$ & $5,47 \%$ \\
\hline 2 & Majalengka & Rp. 283 miliar & $80,92 \%$ & $5,33 \%$ \\
\hline 3 & Bandung & Rp. 270 miliar & $76,30 \%$ & $5,89 \%$ \\
\hline 4 & Sumedang & Rp. 197 miliar & $63,08 \%$ & $5,25 \%$ \\
\hline 5 & Bandung Barat & Rp. 165 miliar & $65,16 \%$ & $5,03 \%$ \\
\hline 6 & Garut & Rp. 257 miliar & $90,20 \%$ & $4,51 \%$ \\
\hline
\end{tabular}

Sumber: Dinas PU Bina Marga tiap-tiap Kabupaten dab BPS Kabupaten Tn 2015

Dari Tabel 2 tersebut di atas dapat dilihat, Kabupaten Cianjur memiliki alokasi anggaran penanganan infrastruktur jalan kabupaten dan kondisi jalan mantap yang paling rendah di antara 6 kabupaten di Jawa Barat. Sementara 5 kabupaten lainnya memiliki alokasi anggaran penanganan infrastruktur jalan rata-rata sudah di atas Rp. 160 miliar dan memiliki kondisi jalan mantap rata-rata di atas $60 \%$.

\subsection{Rumusan Masalah}

Berdasarkan uraian yang telah dikemukakan pada latar belakang tersebut di atas, permasalahan pokok yang akan dibahas dalam policy paper ini adalah:

1. Apakah kondisi jalan mantap yang ada di Kabupaten Cianjur sudah mendukung pertumbuhan ekonomi daerah?

2. Apakah alokasi anggaran infrastruktur jalan Kabupaten Cianjur telah mencapai skala efisiensi untuk meningkatkan kondisi jalan mantap?

3. Faktor-faktor apa saja yang dapat menjelaskan efisiensi anggaran infrastruktur di Kabupaten Cianjur?

\subsection{Tujuan}

Berdasarkan rumusan masalah tersebut di atas, maka tujuan dari penulisan policy paper ini adalah: 
1. Menganalisis pengaruh kualitas infrastruktur jalan terhadap pertumbuhan ekonomi Kabupaten Cianjur.

2. Menganalisis efisiensi alokasi anggaran infrastruktur jalan terhadap kualitas kondisi jalan Kabupaten Cianjur.

\section{4 Ruang Lingkup}

Ruang lingkup yang akan dibahas dalam policy paper ini dibatasi pada masalah pengaruh kualitas infrastruktur jalan Kabupaten Cianjur terhadap pertumbuhan ekonomi Kabupaten Cianjur dan tingkat efisiensi alokasi anggaran infrastruktur jalan terhadap kualitas jalan Kabupaten Cianjur diantara 6 kabupaten di Jawa Barat berdasarkan keadaan pada tahun 2015 .

\section{5 Metodologi}

Metodologi yang digunakan untuk melakukan analisis dalam penulisan policy paper ini adalah menggunakan metode deskriptif kuantitaif berdasarkan hasil analisis efisiensi dengan pendekatan metode Data Envelopment Analysis (DEA).

\section{BAB II PERMASALAHAN}

\section{1 Produk Domestik Regional Bruto (PDRB) Kabupaten Cianjur Masih Rendah}

Berdasarkan data dari Badan Pusat Statistik Kabupaten Cianjur, nilai Produk Domestik Regional Bruto (PDRB) Kabupaten Cianjur atas dasar harga konstan tahun 2010 menurut lapangan usaha pada tahun 2016 sebesar Rp. 26,98 triliun dengan laju pertumbuhan sebesar $6,43 \%$ dan pada tahun 2017 sebesar Rp. 28,52 triliun dengan laju pertumbuhan sebesar $5,72 \%$. Nilai PDRB Kabupaten Cianjur ini termasuk rendah jika dibandingkan dengan PDRB kabupaten lain yang terdapat di Jawa Barat, karena menempati peringkat ke 10 dari 17 kabupaten di Provinsi Jawa Barat, sebagaimana diperlihatkan pada Gambar 1.

Nilai PDRB Kabupaten Cianjur tahun 2013 sebesar Rp. 22,88 triliun dan meningkat menjadi Rp. 28,52 triliun pada tahun 2017, dengan tingkat rata-rata pertumbuhan sebesar $5,51 \%$ pertahun, dan pertumbuhan tertinggi dicapai pada tahun 2016 sebesar 6,43\%. Nilai PDRB Kabupaten Cianjur berdasarkan harga konstan tahun 2010 menurut kategori lapangan usaha dan laju pertumbuhan PDRB dari tahun 2013 sampai tahun 2017 sebagaimana diperlihatkan pada Tabel 3 dan Gambar 2 berikut.

Tabel 3. PDRB Kabupaten Cianjur Atas Dasar Harga Konstan Tahun 2010 Menurut Lapangan Usaha Tahun 2013 - 2017 (dalam Triliun Rp.)

\begin{tabular}{|c|c|c|c|c|c|c|}
\hline \multirow{2}{*}{ No. } & \multirow{2}{*}{$\begin{array}{c}\text { Lapangan } \\
\text { Usaha }\end{array}$} & \multicolumn{5}{|c|}{ PDRB (Triliun Rp.) } \\
\hline & & 2013 & 2014 & 2015 & 2016 & 2017 \\
\hline 1 & $\begin{array}{l}\text { Pertanian, } \\
\text { Kehutanan } \\
\text { dan Perikanan }\end{array}$ & 7,78 & 7,91 & 8,07 & 8,44 & 8,52 \\
\hline 2 & Pertambangan & 0,07 & 0,07 & 0,08 & 0,08 & 0,08 \\
\hline 3 & $\begin{array}{l}\text { Industri } \\
\text { Pengolahan }\end{array}$ & 1,33 & 1,38 & 1,44 & 1,55 & 1,80 \\
\hline 4 & $\begin{array}{l}\text { Listrik, gas } \\
\text { dan Air } \\
\text { Bersih }\end{array}$ & 0,03 & 0,03 & 0,03 & 0,03 & 0,03 \\
\hline 5 & Konstruksi & 1,95 & 2,05 & 2,17 & 2,33 & 2,52 \\
\hline 6 & $\begin{array}{l}\text { Perdagangan, } \\
\text { Hotel dan } \\
\text { Restoran }\end{array}$ & 5,50 & 5,84 & 6,23 & 6,59 & 6,96 \\
\hline 7 & $\begin{array}{l}\text { Transportasi } \\
\text { dan } \\
\text { Komunikasi }\end{array}$ & 2,55 & 2,79 & 3,07 & 3,37 & 3,70 \\
\hline 8 & $\begin{array}{l}\text { Keuangan, } \\
\text { Persewaan } \\
\text { dan Jasa } \\
\text { Perusahaan }\end{array}$ & 1,13 & 1,21 & 1,29 & 1,40 & 1,48 \\
\hline 9 & Jasa Lain-lain & 2,56 & 2,77 & 2,99 & 3,19 & 3,43 \\
\hline & UMLAH & 22,88 & 24,04 & 25,35 & 26,98 & 28,52 \\
\hline
\end{tabular}

Sumber :BPS Kabupaten Cianjur

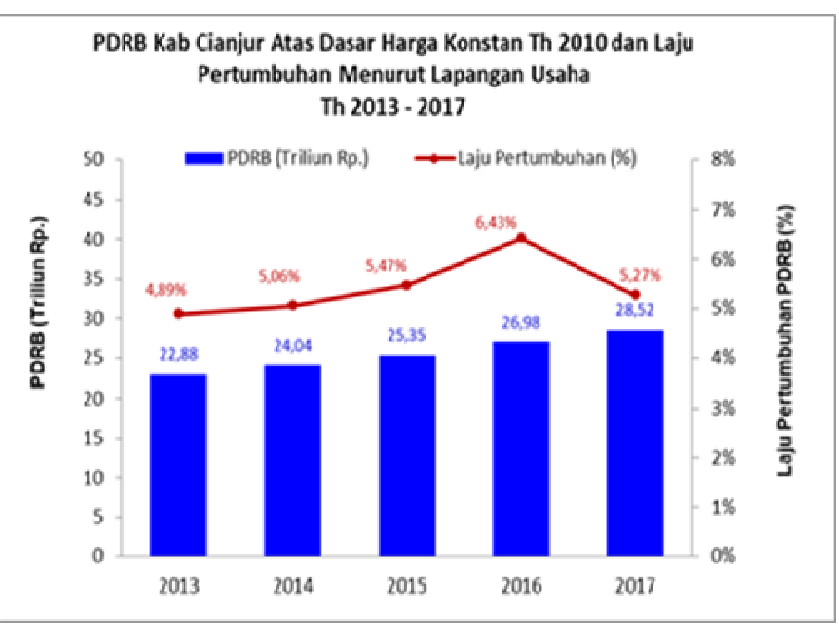

Sumber : Diolah dari data BPS Kabupaten Cianjur

Gambar 3.PDRB Kabupaten Cianjur Atas Dasar Harga Konstan 2010 danLaju Pertumbuhan PDRB Menurut Lapangan Usaha Tahun 2013 2017 
Distribusi sektor-sektor lapangan usaha penyumbang PDRB Kabupaten Cianjur dari tahun 2015 sampai tahun 2017 sebagaimana diperlihatkan pada grafik Gambar 4 berikut.

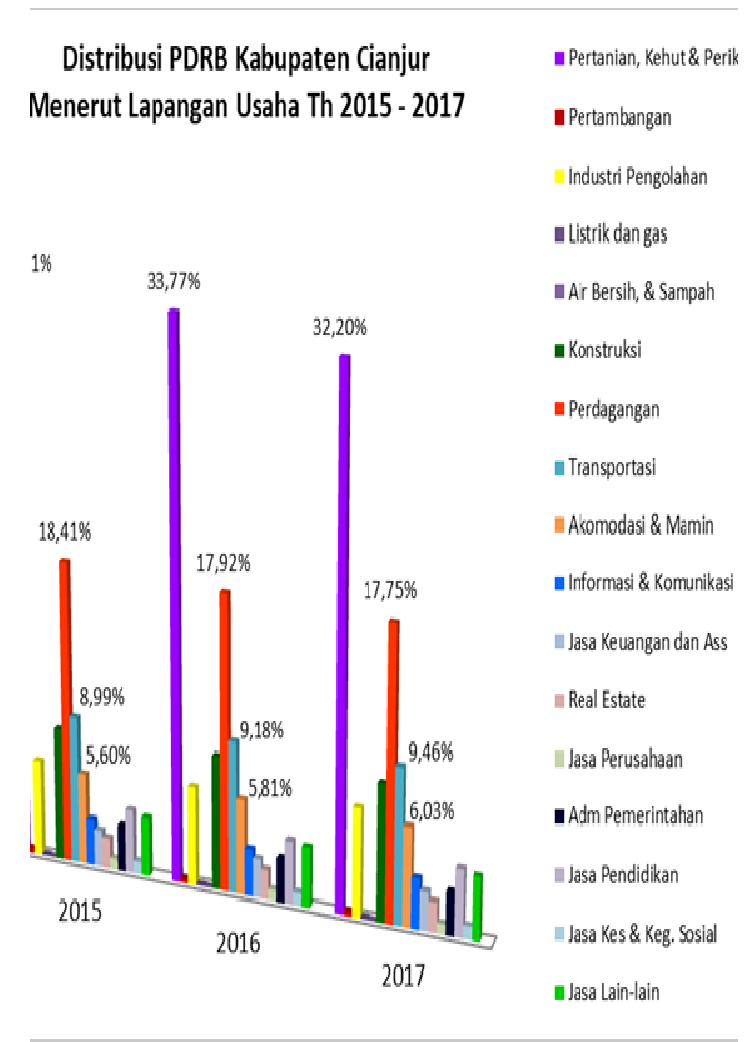

Sumber : Diolah dari data BPS Kabupaten Cianjur

Gambar 2. Distribusi PDRB Kabupaten Cianjur Menurut Lapangan Usaha Tahun $2015-2017$

Dari grafik pada Gambar 4 tersebut di atas dapat dilihat sektor penyumbang terbesar PDRB Kabupaten Cianjur dari tahun 2012 sampai 2017 rata-rata berasal dari sektor Pertanian, Kehutanan, dan Perikanan, kemudian dari sektor perdagangan, berikutnya dari sektor transportasi, kemudian dari sektor akomodasi, makan dan minum. Pada tahun 2016 dari sektor pertanian, kehutanan dan perikanan menyumbang PDRB sebesar $33,77 \%$, sektor Perdagangan menyumbang PDRB sebesar 17,97\%, selanjutnya dari sektor transportasi menyumbang sebesar 9,18\%, kemudian dari sektor akomodasi, makan dan minum menyumbang sebesar 5,81\%.

\section{2 Kualitas Infrastruktur Jalan Kabupaten Cianjur Terendah di Jawa Barat}

Jika diperhatikan Tabel 3 dan Gambar 4 tersebut di atas, terlihat sektror-sektor penyumbang terbesar PDRB Kabupaten Cianjur tahun 2012 - 2017, semuanya terkait atau berhubungan dengan keberadaan atau kondisi infrastruktur daerah, yang salah satunya adalah infrastruktur jalan. Jalan digunakan untuk mengangkut dan memasarkan hasil produksi pertanian, kehutanan dan perikanan. Jalan juga diperlukan di sektor perdagangan, hotel dan restoran, sektor transportasi dan sektor jasa lainnya untuk mendukung kemudahan aksesibilitas dan mobilitas pergerakan barang, manusia dan jasa berupa pengurangan waktu tempuh dan biaya perjalanan.

Di wilayah Kabupaten Cianjur terdapat jalan nasional sepanjang 212,45 km yang terdiri dari jalan arteri primer (JAP) sepanjang 47,48 km yang menghubungkan kota Jakarta dan Bandung melalui kota Sukabumi - Cianjur - Padalarang, dan jalan kolektor primer 1 (JKP-1) sepanjang 164,97 $\mathrm{km}$ yang menghubungkan Bogor dan Cianjur lewat Puncak. Selain jaringan jalan nasional, juga terdapat jaringan jalan provinsi sepanjang $186,400 \mathrm{~km}$ yang fungsinya sebagai jalan Kolektor Primer 2 (JKP-2) sepanjang 137,85 $\mathrm{km}$ dan Kolektor Primer 3 (JKP-3) sepanjang $48,55 \mathrm{~km}$. Kualitas jaringan jalan nasional dan jalan provinsi yang terdapat di wilayah Kabupaten Cianjur pada umumnya dalam kondisi baik (kondisi mantap 100\%).

Adapun jaringan jalan kabupaten, berdasarkan Keputusan Bupati Cianjur Nomor 620/Kep. 168-Binamarga/2013, tentang Penetapan Ruas Jalan Kabupaten Cianjur, panjang ruas Jalan Kabupaten Cianjur adalah $1.301,697 \mathrm{~km}$. Ruas-ruas jalan kabupaten tersebut terdiri dari jalan kolektor 4 (JKP-4), jalan lokal primer (JLP) dan jaringan jalan sekunder di dalam kota.

Jaringan jalan yang berada di wilayah Kabupaten Cianjur sebagaimana diperlihatkan pada Gambar 5 sebagai berikut. 


\section{[URNAL WOMEN}

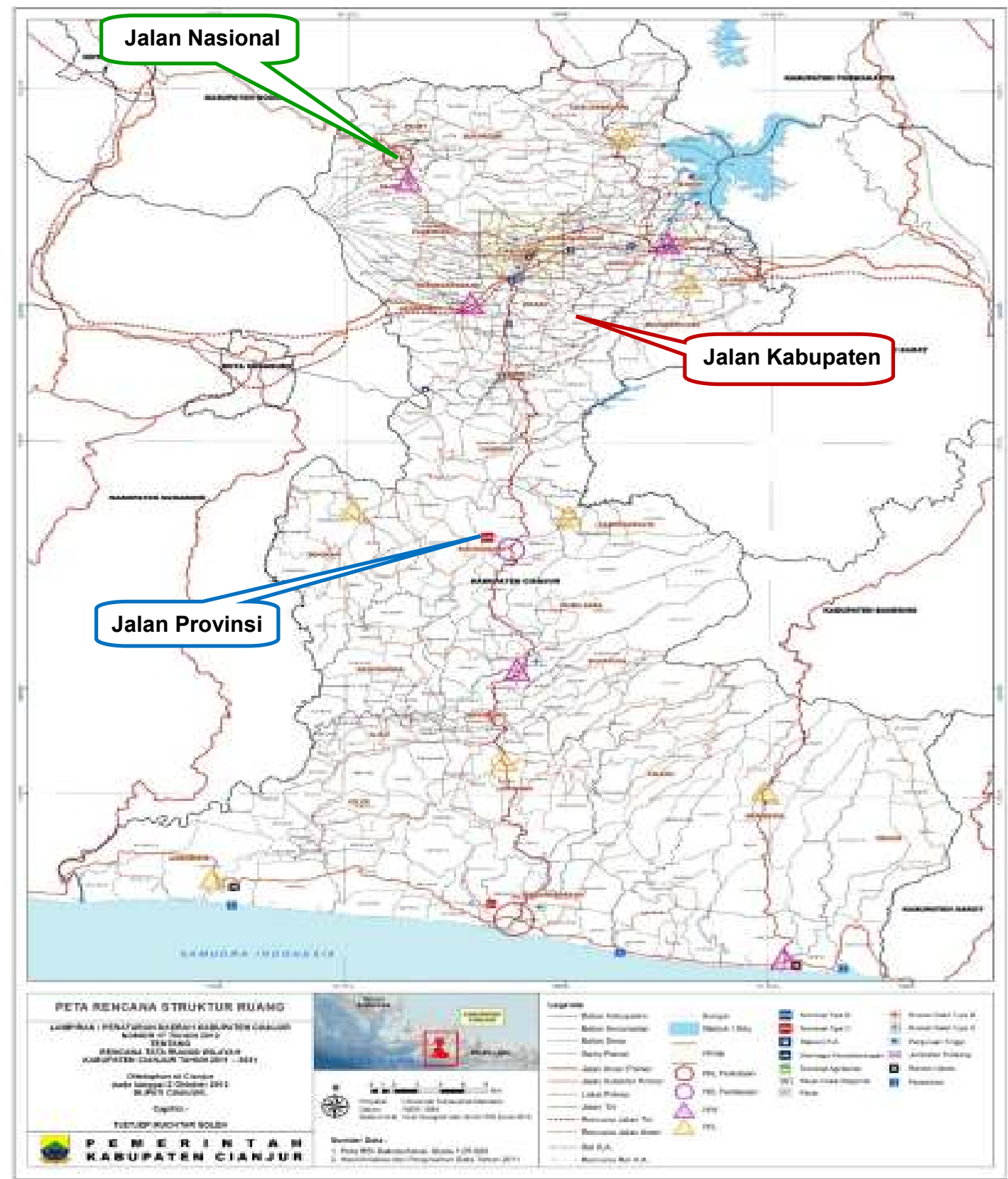

Gambar 3. Peta Jaringan Jalan di Wilayah Kabupaten Cianjur

Kondisi jalan Kabupaten Cianjur pada akhir tahun 2016, dari total panjang jalan kabupten 1.301,697 $\mathrm{km}$ tersebut, 37,87\% dalam kondisi mantap (baik 24,95\% atau sepanjang 324,763 km dan sedang 12,92\% atau sepanjang $168,168 \mathrm{~km}$ ), selebihnya dalam kondisi tidak mantap (rusak 62,13\% atau sepanjang 808,766 km). Sebagaimana dapat di lihat pada Tabel 1, Kabupaten Cianjur memiliki panjang jalan kabupaten terpanjang ke-2 di antara 14 kabupaten di Jawa Barat setelah Kabupaten Bogor. Namum pada tahun
2016 kualitas kondisi jalan Kabupaten Cianjur merupakan yang terendah diantara 14 kabupaten di Jawa Barat, dimana rata-rata kondisi mantap jalan kabupaten di Jawa Barat pada umumnya sudah berada di atas $60 \%$. Kualitas jalan Kabupaten Cianjur yang rendah ini tentunya kurang mendukung terhadap pertumbuhan sektor pertanian yang merupakan sektor penyumbang terbesar PDRB Kabupaten Cianjur. 


\section{3 Alokasi Anggaran Jalan Kabupaten Belum Berhasil Meningkatkan Kualitas Jalan Kabupaten Cianjur Secara Signifikan.}

Sebagaimana telah diamanatkan dalam Undang-undang Nomor 38 Tahun 2004 Tentang Jalan, bahwa pemerintah daerah kabupaten bertanggungjawab dalam penyelenggaraan jalan kabupaten. Salah satu bentuk kegiatan penyelenggaraan jalan tersebut adalah pembangunan jalan yang di dalamya meliputi kegiatan pemrograman dan penganggaran, perencanaan teknis, pelaksanaan konstruksi, serta pengoperasian dan pemeliharaan jalan.

Penganggaran penanganan jalan bertujuan untuk menjaga agar kondisi jalan tetap dapat melayani pergerakan arus lalu lintas kendaraan. Alokasi anggaran jalan tersebut meliputi biaya untuk kegiatan pembangunan/peningkatan jalan, untuk pemeliharaan periodik/rehabilitasi jalan, dan untuk kegitan pemeliharaan rutin jalan. Untuk itu pemerintah kabupaten setiap tahunnya telah mengalokasikan anggaran untuk penanganan jalan kabupaten.

Untuk melihat perkembangan kondisi jalan mantap Kabupaten Cianjur, pada Tabel 4 berikut disajikan data alokasi anggaran penangan jalan dan perkembangan kualitas kondisi jalan mantap Kabupaten Cianjur tahun $2014-2017$.

Tabel 4 . Alokasi Anggaran Penanganan Jalan dan Kondisi Jalan Mantap Kabupaten Cianjur

Tahun 2014 - 2017

\begin{tabular}{|c|c|c|c|c|c|c|c|c|c|c|}
\hline \multirow{2}{*}{$\begin{array}{c}\text { Jenis Penanganan } \\
\text { Jalan }\end{array}$} & \multicolumn{2}{|c|}{2014} & \multicolumn{2}{|c|}{2015} & \multicolumn{2}{|c|}{2016} & \multicolumn{2}{|c|}{2017} & \multicolumn{2}{|c|}{2018} \\
\hline & $\begin{array}{l}\text { Miliar } \\
\text { Rp. }\end{array}$ & $\%$ & $\begin{array}{l}\text { Miliar } \\
\text { Rp. }\end{array}$ & $\%$ & $\begin{array}{c}\text { Miliar } \\
\text { Rp. }\end{array}$ & $\%$ & $\begin{array}{c}\text { Miliar } \\
\text { Rp. }\end{array}$ & $\%$ & $\begin{array}{c}\text { Miliar } \\
\text { Rp. }\end{array}$ & $\%$ \\
\hline Pemb/Peningkt Jalan & 42,624 & 75,21 & 83,500 & 84,28 & 117,004 & 60,01 & 313,066 & 83,54 & 367.415 & 78,79 \\
\hline $\begin{array}{l}\text { Pemel Periodik/ } \\
\text { Rehab Jalan }\end{array}$ & 5,565 & 9,82 & 7,729 & 7,80 & 68,537 & 35,15 & 51,451 & 13,73 & 83.895 & 17,99 \\
\hline Pemel Rutin Jalan & 8,483 & 14,97 & 7,847 & 7,92 & 9,446 & 4,85 & 10,213 & 2,73 & 15.000 & 3,22 \\
\hline JUMLAH & 56,672 & 100,00 & 99,076 & 100,00 & 194,987 & 100,00 & 374,739 & 100,00 & 466,310 & 100,00 \\
\hline $\begin{array}{c}\text { Persentase Terhadap } \\
\text { APBD }\end{array}$ & \multicolumn{2}{|c|}{$2,16 \%$} & \multicolumn{2}{|c|}{$2,96 \%$} & \multicolumn{2}{|c|}{$6,01 \%$} & \multicolumn{2}{|c|}{$10,23 \%$} & \multicolumn{2}{|c|}{$11,61 \%$} \\
\hline Kondisi Jalan Mantap & \multicolumn{2}{|c|}{$35,56 \%$} & \multicolumn{2}{|c|}{$35,88 \%$} & \multicolumn{2}{|c|}{$37,87 \%$} & \multicolumn{2}{|c|}{$40,53 \%$} & \multicolumn{2}{|c|}{$50,98 \%$} \\
\hline
\end{tabular}

Sumber : diolah dari LKPJ Bupati Cianjur dan Renstra Dinas PUPR Th 2016-2021

Dari Tabel 4 tersebut di atas dapat dilihat anggaran untuk penanganan jalan kabupaten yang telah dialokasikan oleh Pemerintah Kabupaten Cianjur dari tahun 2014 - 2018 ternyata hanya dapat menghasilkan kondisi mantap jalan kabupaten sebesar 50,98\% pada tahun 2018. Kondisi ini masih sangat jauh di bawah rata-rata kondisi mantap jalan kabupaten di Jawa Barat yang sudah mencapai di atas $60 \%$.

\section{BAB III STUDI LITERATUR}

\section{1 Pengaruh Infrastruktur Jalan Terhadap Pertumbuhan Ekonomi}

Ketersediaan infrastruktur dengan pembangunan ekonomi mempunyai hubungan yang erat dan saling ketergantungan satu sama lain. Infrastruktur jalan merupakan salah satu infrastruktur transportasi yang berperan dalam merangsang pertumbuhan ekonomi suatu daerah. Ketersediaan infrastruktur jalan yang baik akan meminimalkan biaya transportasi untuk mendistribusikan hasil produksi suatu 
wilayah untuk diangkut menuju ke lokasi pemasaran. Perbaikan dan peningkatan infrastruktur jalan pada umumnya akan dapat meningkatkan mobilitas penduduk, terciptanya penurunan ongkos pengiriman barang-barang, dan terdapatnya pengangkutan barang-barang dengan kecepatan yang lebih tinggi, serta perbaikan kualitas dari jasa-jasa pengangkutan tersebut. Sehingga dengan tersedianya infrastruktur jalan yang baik, proses produksi dan distribusi barang dan jasa menjadi lebih efisien.

Pembangunan prasarana jalan juga turut meningkatkan pertumbuhan suatu wilayah. Sebaliknya prasarana jalan yang buruk dan rusak akan menghambat alokasi sumber daya, pengembangan industri, pendistribusian hasil produksi, barang dan jasa suatu daerah.

Dalam Undang-undang Nomor 38 Tahun 2004 tentang Jalan, dijelaskan bahwa peran infrastruktur jalan adalah sebagai bagian dari prasarana transportasi yang mempunyai peran penting dalam bidang ekonomi, sosial budaya, lingkungan hidup, politik, pertahanan dan keamanan.

\section{2 Pengelolaan Jalan Kabupaten}

Undang-undang Nomor 38 Tahun 2004 Tentang Jalan mengamanatkan bahwa Pemerintah Kabupaten bertanggungjawab dalam penyelenggaraan jalan kabupaten. Kewenangan tersebut dipertegas lagi dalam Undang-undang Nomor 23 Tahun 2014 Tentang Pemerintahan Daerah, bahwa urusan pemerintahan bidang pekerjan umum, sub urusan jalan, pemerintah daerah kabupaten bertanggungjawab dalam penyelenggaraan jalan kabupaten. Wewenang penyelenggaraan jalan kabupaten sebagaimana dijelaskan pada Pasal 16 ayat (3) Undang-undang Nomor 38 Tahun 2004 meliputi pengaturan, pembinaan, pembangunan, dan pengawasan. Selanjutnya dijelaskan dalam Pasal 30 ayat (1) huruf b, bahwa penyelenggara jalan wajib memrioritaskan pemeliharaan, perawatan dan pemeriksaan jalan secara berkala untuk mempertahankan tingkat pelayanan jalan sesuai dengan standar pelayanan minimal yang ditetapkan.

\section{3 Penanganan Jalan Kabupaten di Indonesia}

Untuk menjaga kelancaran pergerakan orang, arus barang dan jasa, dibutuhkan kondisi jalan yang dalam kondisi baik. Sehubungan dengan hal tersebut diperlukan adanya penangan jalan agar tetap terjaga kondisinya dalam melayani arus lalu lintas pergerakan orang, barang dan jasa.

Berdasarkan Surat Keputusan Dirjen Bina Marga No. 77/KPTS/Db/1990 Tentang Petunjuk Teknis Perencanaan dan Penyusunan Program Jalan Kabupaten, kondisi jalan dibagi menjadi dua bagian, meliputi:

1. Jalan mantap (stabil), jalan yang kondisinya baik dan sedang, yaitu jalan yang dari kondisi baru dibangun sampai dengan kondisi pelayanan pada batas kemantapan (akhir umur rencana pelayanan), dengan penurunan nilai kemantapan wajar seperti yang diperhitungkan dalam perencanaan teknis.

2. Jalan tidak mantap (tidak stabil), yaitu jalan dalam kondisi rusak/rusak berat, yaitu jalan yang kondisi pelayanannya berada diantara batas kemantapan sampai dengan batas kritis.

Untuk menentukan kondisi jalan dapat dilakukaan dengan beberapa cara. Salah satunya berdasarkan nilai dari indeks kondisi jalan (Road Condition Index, RCI), yaitu tingkat kekasaran permukaan jalan yang diperoleh dengan melakukan survei secara visual. Kondisi jalan berdasarkan nilai RCI sebagaimana Lampiran I Peraturan Menteri Pekerjaan Umum Nomor 47/PRT/M/2015 Tentang Petunjuk Teknis Penggunaan Dana Alokasi Khusus Bidang Infrastruktur sebagaimana diperlihatkan pada Tabel 5 berikut. 
Tabel 5. Kondisi Jalan berdasarkan Nilai RCI

\begin{tabular}{|c|l|c|c|}
\hline $\begin{array}{c}\text { No } \\
.\end{array}$ & \multicolumn{1}{|c|}{ Jenis Permukaan Jalan } & \multicolumn{1}{|c|}{$\begin{array}{c}\text { Kondisi ditinjau secara } \\
\text { visual }\end{array}$} & $\begin{array}{c}\text { Niali } \\
\text { RCI }\end{array}$ \\
\hline 1. & $\begin{array}{l}\text { Jalan tanah dengan drainase yang jelek, dan } \\
\text { semua tipe jalan yang tidak diperkeras }\end{array}$ & Tidak dapat dilalui & $0-2$ \\
\hline 2. & $\begin{array}{l}\text { Semua tipe perkerasan jalan yang tidak } \\
\text { diperhatikan sejak lama (4 - 5 th atau lebih) }\end{array}$ & $\begin{array}{c}\text { Rusak berat, banyak lubang di } \\
\text { seluruh daerah perkerasan }\end{array}$ & $2-3$ \\
\hline 3. & Lapen lama, Latasbum lama, batu kerikil & $\begin{array}{c}\text { Rusak bergelombang, banyak } \\
\text { lubang }\end{array}$ & $3-4$ \\
\hline 4. & $\begin{array}{l}\text { Lapen setelah pemakaian 2 tahun, } \\
\text { Latasbum lama }\end{array}$ & $\begin{array}{c}\text { Agak rusak, kadang-kadang } \\
\text { ada lubang, permukaan tidak } \\
\text { rata }\end{array}$ & $4-5$ \\
\hline 5. & $\begin{array}{l}\text { Lapen baru, Latasbum baru, Lasbutag } \\
\text { setelah pemakaian 2 tahun }\end{array}$ & $\begin{array}{c}\text { Cukup tidak ada atau sedikit } \\
\text { sekali lubang, permukaan jalan } \\
\text { agak tidak rata }\end{array}$ & $5-6$ \\
\hline 6. & $\begin{array}{l}\text { Lapis tipis lama dari Hotmix, Latasbum } \\
\text { baru, Lasbutag baru }\end{array}$ & Baik & $6-7$ \\
\hline 7. & $\begin{array}{l}\text { Hotmix setelah 2 tahun, Hotmix tipis di atas } \\
\text { PM }\end{array}$ & Sangat baik, umumnya rata & $7-8$ \\
\hline 8. & $\begin{array}{l}\text { Hotmix baru (Lataston, Laston), } \\
\text { Peningkatan dengan menggunakan lebih } \\
\text { dari 1 lapis }\end{array}$ & Sangat rata dan teratur & $8-10$ \\
\hline
\end{tabular}

Sumber : Permen PU No. 47/PRT/M/2015

Berdasarkan pengertian yang terdapat di dalam Lampiran I Peraturan Menteri Pekerjaan Umum dan Perumahan Rakyat Nomor 47/PRT/M/2015 Tentang Petunjuk Teknis Penggunaan Dana Alokasi Khusus (DAK) Bidang Infrastruktur, yang dimaksud dengan:

- Pemeliharaan Rutin (PR) adalah kegiatan merawat serta memperbaiki kerusakankerusakan yang terjadi pada ruas-ruas jalan dengan kondisi pelayanan mantap;

- Rehabilitasi Jalan merupakan kegiatan penanganan terhadap setiap kerusakan yang tidak diperhitungkan dalam desain, yang berakibat menurunnya kondisi kemantapan pada bagian/tempat tertentu dari suatu ruas jalan dengan kondisi rusak ringan, agar kondisi kemantapan tersebut dapat dikembalikan sesuai dengan rencana;

- Pemeliharaan Berkala (PM) adalah kegiatan penanganan terhadap setiap kerusakan yang diperhitungkan dalam desain, agar penurunan kondisi jalan dapat dikembalikan pada kondisi kemantapan sesuai dengan rencana;

- Peningkatan Jalan (PK) adalah kegiatan penanganan untuk dapat meningkatkan kemampuan ruas-ruas jalan dalam kondisi tidak mantap atau kritis agar ruas jalan tersebut dalam kondisi mantap sesuai dengan umur rencana. Peningkatan kapasitas merupakan penanganan jalan dengan pelebaran perkerasan, baik menambah maupun tidak menambah jumlah lajur;

- Pembangunan Jalan adalah kegiatan membangun jalan tanah/jalan setapak menjadi standar jalan minimum sesuai dengan tingkat kebutuhan lalu lintas dan sesuai dengan standar/pedoman yang berlaku.

\section{4 Metode Data Envelopment Analysis (DEA)}

Data Envelopment Analysis (DEA) adalah suatu pendekatan yang relatif baru untuk mengevaluasi kinerja dari suatu entitas yang disebut Decision Making Units (DMU) yang mengubah beberapa input menjadi 
beberapa output. Beberapa tahun terakhir ini telah terlihat berbagai macam aplikasi DEA untuk digunakan dalam mengevaluasi kinerja berbagai jenis entitas yang terlibat dalam berbagai kegiatan di banyak negara. Aplikasi DEA ini telah digunakan oleh DMU dari berbagai bentuk untuk mengevaluasi kinerja entitas, seperti rumah sakit, Angkatan Udara AS, universitas, kota, pengadilan, perusahaan bisnis, termasuk kinerja negara, wilayah, dan lain-lain. Karena DEA memerlukan sangat sedikit asumsi, DEA juga telah membuka kemungkinan untuk digunakan dalam kasuskasus yang telah resisten terhadap pendekatan lain karena sifat hubungan yang kompleks (sering tidak diketahui) antara beberapa input dan beberapa output yang terlibat dalam DMU (Cooper, Seiford and Joe, 2011).

Data Envelopment Analisys (DEA) adalah suatu metode nonparametrik yang menggunakan teknik pemrograman linier yang digunakan untuk mengevaluasi efisiensi relatif dari suatu unit pengambilan keputusan (Decision Making Unit, DMU). Berdasarkan data-data yang tersedia dari semua unit yang dianalisis, sebuah batas/garis efisien (efficient frontier) dapat dibentuk. Unit-unit yang berada pada batas/garis efisien ini dikatakan sebagai unit yang efisien (relative efficient) dan unitunit yang berada di luar batas/garis ini dikatakan sebagai unit-unit yang tidak efisien. Unit yang menghasilkan output maksimum dari input yang diberikan dikatakan sebagai analisis berorintasi kepada output (outputoriented $D E A)$, atau unit-unit yang menggunakan input minimum untuk menghasilkan output yang diberikan dikatakan sebagai analisis berorientasi kepada input (input-oriented DEA). Unit-unit yang menghasilkan output maksimum atau unit-unit yang menggunakan input minimum ini terletak pada batas/garis efisiensi (Cooper et al., 2006, dalam Molinos and Encinas, 2016).

Gambar 6 berikut memperlihatkan contoh sederhana analisis menggunakan metode pendekatan DEA yang berorientasi kepada input (input-oriented approach), di mana setiap unit menggunakan satu input untuk menghasilkan satu output. Dengan cara yang sama konsep ini dapat diterapkan pada proses produksi lainnya dengan menggunakan banyak input dan/atau output. A sampai $\mathrm{F}$ mewakili enam unit yang akan dievaluasi tingkat efisiensinya. Unit A sampai D adalah unit-unit efisien yang terletak pada batas/garis produksi yang efisien (the efficient production frontier). Unit $\mathrm{E}$ dan $\mathrm{F}$ adalah unit-unit yang inefisien karena unit-unit tersebut dapat mengurangi penggunaan input untuk menghasilkan tingkat output yang sama (Molinos and Encias, 2016).

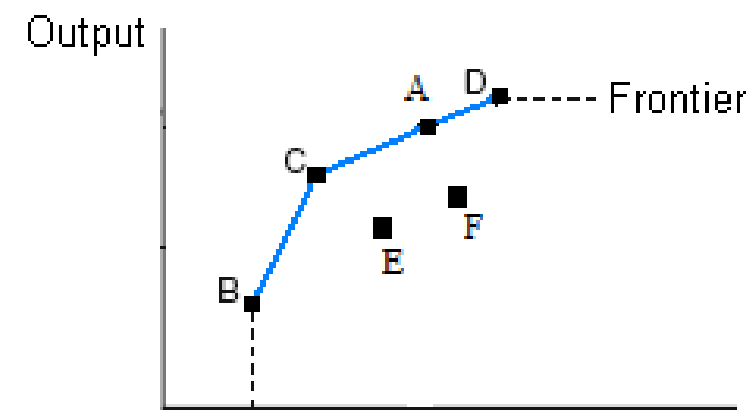

Input

Sumber : Molinos and Encinas, 2016

Gambar 6. Contoh Grafik Data Envelopment Analysis

Tergantung pada bagaimana input digabungkan untuk menghasilkan output, model DEA dapat dikatakan sebagai mencapai skala hasil konstan (Constant Returns to Scale, (CRS) (Charnes et al., 1978) atau mencapai skala hasi yang variabel (Variable Returns to Scale, VRS) (Banker et al., 1982) (dalam Molinos and Encias, 2016).

- Jika output meningkat dalam proporsi yang sama dengan input, maka model tersebut dikatakan mencapai skala hasil yang konstan (CRS);

- Jika output meningkat dalam proporsi yang tidak sama dengan input, model tersebut mencapai skala hasil yang variabel (VRS).

\subsection{Pengaruh Infrastruktur Jalan Terhadap Pertumbuhan Ekonomi}

Beberapa penelitian terdahulu menyatakan adanya pengaruh infrastruktur jalan terhadap pertumbuhan ekonomi di suatu daerah. Hasil penelitian tersebut diantaranya:

1. Laen Sugi (2015) dalam penelitiannya yang berjudul Analisis Pengaruh Infrastruktur Terhadap Pertumbuhan Ekonomi Kabupaten Mamasa Periode 
2003 - 3013 menyimpulkan, pengaruh rasio infrastruktur jalan rusak terhadap pertumbuhan ekonomi menunjukkan berkorelasi positif namun tidak signifikan terhadap pertumbuhan ekonomi. Sedangkan kondisi jalan baik yang jumlahnya semakin menurun memiliki hubungan negatif terhadap pertumbuhan ekonomi.

2. Indayani Hasim (2013) dalam penelitiannya yang berjudul Analisis Keterkaitan Transportasi Darat Dengan Pertumbuhan Ekonomi di Kabupaten Merauke Periode 2002 - 2011 menyimpulkan, pembiayaan jalan mempunyai pengaruh positif dan signifikan terhadap pertumbuhan ekonomi di Kabupaten Merauke.

3. Nugroho Maku (2011) dalam penelitiannya yang berjudul Analisis Determinansi Infrastruktur Jalan Terhadap Produk Domestik Regional Bruto (Studi Kasus di Provinsi Nusa Tenggara Timur) menyimpulkan, infrastruktur jalan berpengaruh signifikan terhadap Produk Domestik Regional Bruto (PDRB) di Provinsi Nusa Tenggara Timur.

4. Adi Pramomo (2011) dalam penelitiannya yang berjudul Pengaruh Pembangunan Infrastruktur Jalan Dan Listrik Terhadap Pertumbuhan Ekonomi Di Kalimantan Tahun 1994 - 2008 menyimpulkan, Infrastruktur jalan signifikan memberikan pengaruh yang positif terhadap pertumbuhan ekonomi di Kalimantan.

\section{6 Target Kondisi Mantap Jalan Kabupaten Cianjur Tahun 2021}

Di dalam dokumen RPJMD kabupaten Cianjur tahun 2016 - 2021, ditetapkan target sasaran yang ingin dicapai di bidang infrastruktur jalan, yaitu persentase kondisi mantap jalan kabupaten sebesar $70 \%$ pada akhir tahun 2021. Adapun tahapan target pencapaian setiap tahunnya sebagaimana diperlihatkan pada Tabel 6 sebagai berikut.

Tabel 6 Misi, Tujuan dan Sasaran RPJMD Kab. Cianjur Th 2016 - 2021 Bidang

Infrastruktur Jalan

\begin{tabular}{|c|c|c|c|c|c|c|c|c|c|}
\hline \multirow{2}{*}{ Misi } & \multirow{2}{*}{ Tujuan } & \multirow{2}{*}{ Sasaran } & \multirow{2}{*}{$\begin{array}{c}\text { Indikator } \\
\text { Kinerja } \\
\text { Sasaran }\end{array}$} & \multicolumn{6}{|c|}{ Target RPJMD } \\
\hline & & & & 2016 & 2017 & 2018 & 2019 & 2020 & 2021 \\
\hline $\begin{array}{l}\text { Meningkatkan } \\
\text { pembangunan } \\
\text { infrastruktur } \\
\text { yang } \\
\text { terintegrasi } \\
\text { dan } \\
\text { berwawasan } \\
\text { lingkungan }\end{array}$ & $\begin{array}{l}\text { Meningkatkan } \\
\text { kualitas dan } \\
\text { cakupan } \\
\text { pelayanan } \\
\text { infrastruktur } \\
\text { wilayah } \\
\text { dengan } \\
\text { menerapkan } \\
\text { pembangunan } \\
\text { berwawasan } \\
\text { lingkungan }\end{array}$ & $\begin{array}{l}\text { Meningkat } \\
\text { nya } \\
\text { pembangu } \\
\text { nan } \\
\text { infrastrukt } \\
\text { ur daerah }\end{array}$ & $\begin{array}{l}\text { Persentase } \\
\text { kondisi } \\
\text { mantap } \\
\text { jalan } \\
\text { kabupaten }\end{array}$ & $\begin{array}{c}36,35 \\
\%\end{array}$ & $\begin{array}{c}44,00 \\
\%\end{array}$ & $\begin{array}{c}52,00 \\
\%\end{array}$ & $\begin{array}{c}60,00 \\
\%\end{array}$ & $\begin{array}{c}65,00 \\
\%\end{array}$ & $\begin{array}{c}70,00 \\
\%\end{array}$ \\
\hline
\end{tabular}

\section{BAB IV PEMBAHASAN}

\section{1 Tingkat Efisiensi Kualitas Jalan Kabupaten Terhadap Pertumbuhan Ekonomi Kabupaten di Jawa Barat}

Untuk mengetahui tingkat efisiensi kualitas jalan dalam mendukung pertumbuhan ekonomi di beberapa daerah kabupaten di Jawa Barat, dilakukan studi kasus terhadap 6 kabupaten di Jawa Barat berdasarkan kualitas jalan kabupaten dan pertumbuhan ekonomi pada tahun 2015 dengan menggunakan metode Data Envelopment Analysis (DEA).

Kabupaten tersebut terdiri dari Kabupaten Cianjur, Kabupaten Majalengka, Kabupaten Bandung, Kabupaten Sumedang, Kabupaten Bandung Barat dan Kabupaten Garut. Alasan dipilihnya 6 kabupten tersebut dikarenakan ketersediaan data yang cukup memadai, jika dibandingkan dengan 
kabupaten/kota lainnya yang ada di Jawa Barat.

Hasil analisis efisiensi korelasi kualitas jalan (kondisi mantap) terhadap pertumbuhan ekonomi dengan menggunakan metode Data
Envelopment Analysis (DEA) terhadap 6 kabupaten di Jawa Barat, ditampilkan pada Tabel 7 sebagai berikut.

Tabel 7. Kualitas Jalan dan Efisiensi Tingkat Pertumbuhan Ekonomi 6 Kabupaten di Jawa Barat Tahun 2015

\begin{tabular}{|c|c|c|c|c|c|c|}
\hline No & $\begin{array}{c}\text { KABUPAT } \\
\text { EN }\end{array}$ & $\begin{array}{l}\text { KUALIT } \\
\text { AS } \\
\text { JALAN }\end{array}$ & $\begin{array}{c}\text { PERTUMBUH } \\
\text { AN } \\
\text { EKONOMI }\end{array}$ & $\begin{array}{c}\text { TARGET } \\
\text { PERTUMBU } \\
\text { HAN } \\
\text { EKONOMI }\end{array}$ & $\begin{array}{l}\text { EFISIEN } \\
\text { SI }\end{array}$ & $\begin{array}{l}\text { INEFISIE } \\
\text { NSI }\end{array}$ \\
\hline 1 & Cianjur & $35,88 \%$ & $5,47 \%$ & $9,15 \%$ & $32,80 \%$ & $67,20 \%$ \\
\hline 2 & Majalengka & $80,92 \%$ & $5,33 \%$ & $6,61 \%$ & $75,90 \%$ & $24,10 \%$ \\
\hline 3 & Bandung & $76,30 \%$ & $5,89 \%$ & $7,96 \%$ & $64,80 \%$ & $35,20 \%$ \\
\hline 4 & Sumedang & $63,08 \%$ & $5,25 \%$ & $7,35 \%$ & $60,10 \%$ & $39,90 \%$ \\
\hline 5 & $\begin{array}{l}\text { Bandung } \\
\text { Barat }\end{array}$ & $65,16 \%$ & $5,03 \%$ & $6,80 \%$ & $64,80 \%$ & $35,20 \%$ \\
\hline 6 & Garut & $90,20 \%$ & $4,51 \%$ & $4,51 \%$ & $100,00 \%$ & $0,00 \%$ \\
\hline
\end{tabular}

Sumber : Hasil Analisis Menggunakan Metode DEA

Dari hasil analisis pada Tabel 7 tersebut di atas, dibuat grafik efisiensi kualitas jalan terhadap pertumbuhan ekonomi dan garis kecenderungan (trend line) target pertumbuhan ekonomi kabupaten yang efisien terhadap kualitas jalan, yang disebut dengan garis efisien (efficient frontier). Grafik tersebut ditampilkan pada Gambar 7 sebagai berikut.

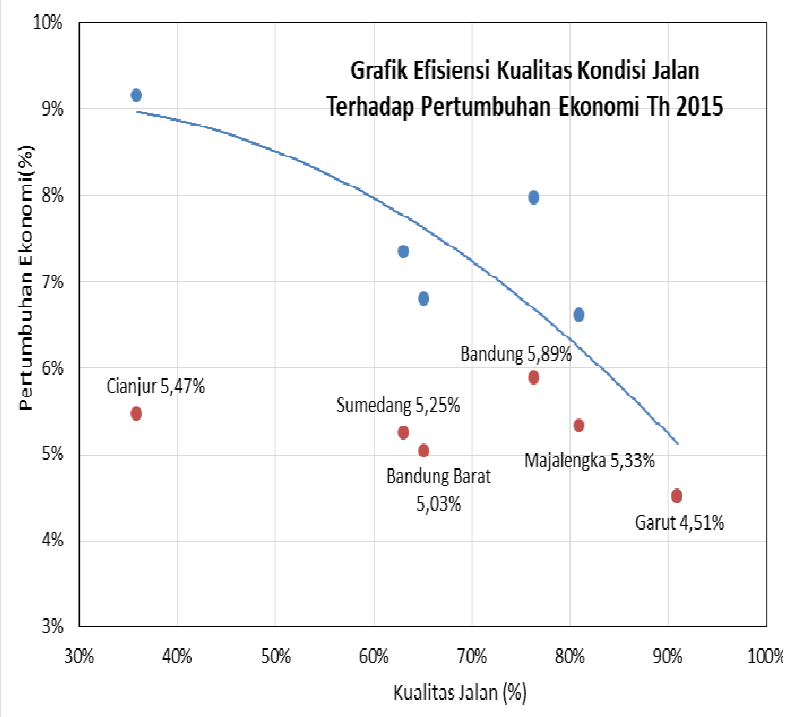

Gambar 7. Grafik Efisiensi Kualitas Jalan (Jalan Mantap) Terhadap Pertumbuhan
Ekonomi (PDRB) 6 Kabupaten di Jawa Barat Th 2015

Dari Gambar 7 tersebut di atas, terlihat garis pertumbuhan ekonomi yang efisien (efficient frontier) cenderung menurun seiring

dengan meningkatnya kualitas jalan. Hal ini dapat dikatakan bahwa berdasarkan kondisi pada tahun 2015 peningkatan kualitas jalan kabupaten di 6 kabupaten di Jawa Barat, tidak berpengaruh positif terhadap pertumbuhan ekonomi 6 kabupaten di Jawa Barat tersebut. Hal ini bertolak belakang dengan beberapa hasil penelitian yang telah dilakukan sebelumnya, dimana dikatakan bahwa kualitas infrastruktur jalan berpengaruh positif terhadap pertumbuhan ekonomi (Laen Sugi, 2015, Hasyim 2013, etc). Dari Gambar 8 tersebut juga dapat dilihat bahwa pertumbuhan ekonomi di 6 kabupaten di Jawa Barat masih berada di bawah garis efisien. Menurut teori DEA, unit-unit yang berada di luar batas/garis ini dikatakan sebagai unit-unit yang tidak efisien. Oleh karena itu dapat dikatakan bahwa kualitas jalan kabupaten di 6 kabupaten tersebut belum mencapai skala efisiensi dalam mendukung pertumbuhan ekonomi daerah kabupaten.

Kualitas jalan (kondisi jalan mantap) dikatakan mencapai skala efisiensi apabila 


\section{IUURAL MOMEN}

kualitas jalan (persentase jalan dalam kondisi mantap) dapat mendukung pertumbuhan ekonomi daerah yang tinggi. Hal ini dapat ditunjukkan bila pertumbuhan ekonomi yang terjadi berada pada garis efisien (efficient frontier) pada Gambar 7.

Untuk Kabupaten Cianjur inefisiensi kualitas jalan terjadi karena sektor pertanian dan kehutanan, yang merupakan penyumbang terbesar pertumbuhan ekonomi Kabupaten Cianjur, tidak didukung oleh kualitas kondisi jaringan jalan yang baik. Hal tersebut karena kondisi jalan kabupaten yang berada di kawasan pertanian yang berfungsi menghubungkan pusat-pusat produksi pertanian dengan lokasi pemasaran pada umumnya dalam kondisi rusak, sebagaimana diperlihatkan pada Gambar 8 dan Gambar 9. Sehingga rendahnya kualitas jalan tersebut berakibat kepada rendahnya tingkat produktivitas hasil pertanian.

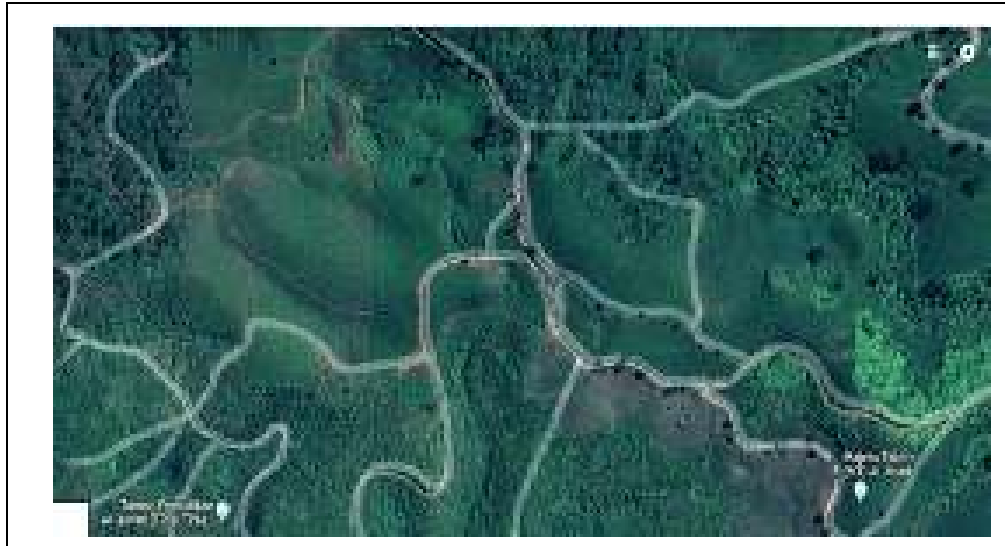

Gambar 8. Jaringan Jalan Kabupaten Pada Kawasan Pertanian Dalam Kondisi Rusak

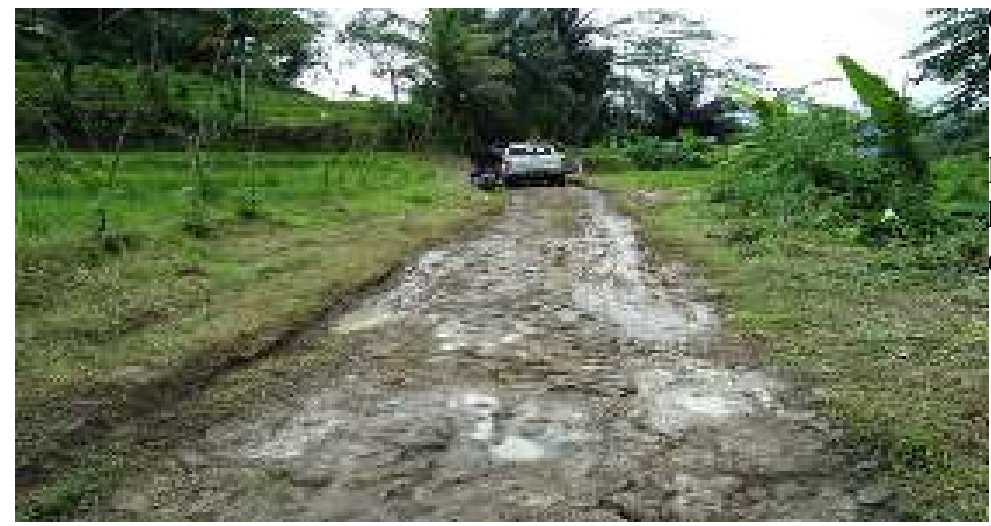

Gambar 9. Jalan Kabupaten Dalam Kondisi Rusak Pada Kawasan Pertanian

\section{2 Pengaruh Kualitas Jalan Kabupaten Cianjur Terhadap Pertumbuhan Ekonomi}

Untuk mengetahui pengaruh kualitas infrastruktur jalan kabupaten terhadap pertumbuhan ekonomi Kabupaten Cianjur, dilakukan pemetaan distribusi PDRB Kabupaten Cianjur pada matriks korelasi distribusi PDRB dan kualitas infrastruktur jalan kabupaten sebagaimana diperlihatkan pada Gambar 10 sebagai berikut.

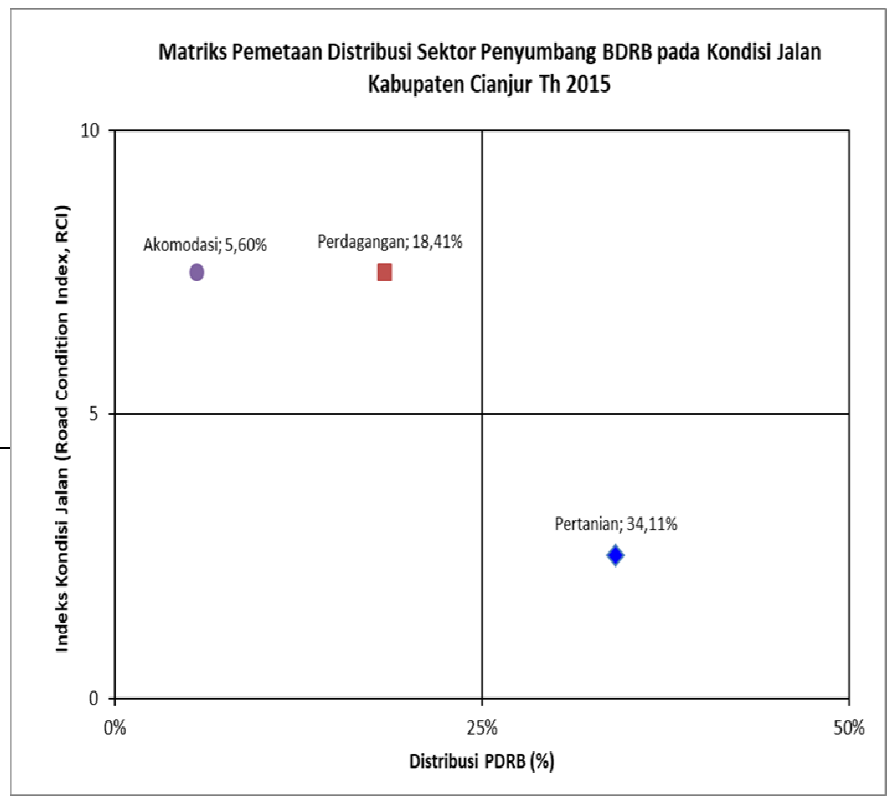

Gambar 10. Matriks Pemetaan Distribusi PDRB Pada Kualitas Jalan Kabupaten Cianjur Tahun 2015

Gambar 10 memperlihatkan matriks pemetaan distribusi sektor lapangan usaha penyumbang terbesar PDRB Kabupaten Cianjur pada kondisi jalan di Kabupaten Cianjur pada tahun 2015.

Dari pemetaan tersebut sektor lapangan usaha penyumbang PDRB terhadap kondisi jalan Kabupaten Cianjur dapat dijelaskan sebagai berikut :

Sektor penyediaan akomodasi (perhotelan), makan dan minum mempunyai kontribusi terhadap PDRB sebesar 5,60\% dan sektor perdagangan besar dan eceran, reparasi mobil dan sepeda motor mempunyai kontribusi terhadap PDRB sebesar 18,41\%. Dua sektor tersebut berada di kuadran II, dimana kuadran tersebut menunjukkan ruas-ruas jalan dengan kondisi mantap (baik dan sedang). Untuk Kabupaten Cianjur, 
sektor-sektor tersebut sebagian besar berada pada ruas jalan nasional dan ruas-ruas jalan kabupaten yang kondisinya sudah mantap. Sektor-sektor ini pada umumnya berlokasi di Kecamatan Cipanas dan Pacet yang merupakan kawasan wisata, sebagaimana diperlihatkan pada peta Gambar 11. Walaupun sektor-serktor ini berapa pada ruas-ruas jalan dengan kondisi mantap, namun karena kontribusinya terhadap PDRB kecil, sehingga kurang mendukung terhadap pertumbuhan PDRB Kabupaten Cianjur.

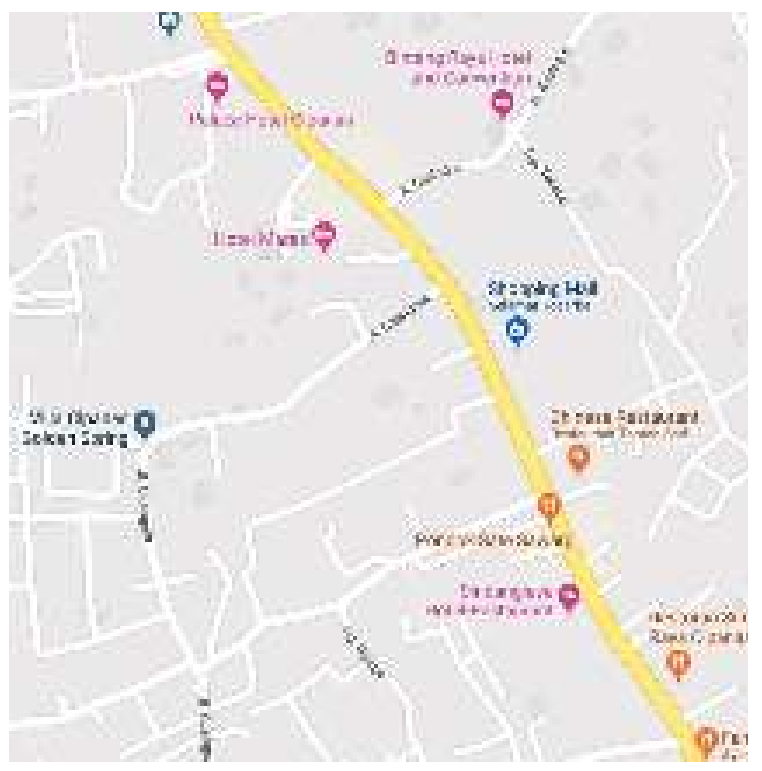

Gambar 4. Peta Lokasi Hotel, Restoran dan Pertokoaan Di Kota Cipanas Pada Ruas Jalan Nasional dan Jalan Kabupaten Dalam Kondisi Mantap

- Sektor pertanian, kehutanan dan perikanan merupakan sektor lapangan usaha penyumbang terbesar PDRB Kabupaten Cianjur, dengan kontribusi terhadap PDRB sebesar $34,11 \%$ pada tahun 2015. Sektor ini berada pada kuadran IV, yaitu kuadran dengan kondisi jalan tidak mantap (rusak). Ini berarti sektor pertanian dan kehutanan yang merupakan penyumbang terbesar PDRB Kabupaten Cianjur tidak didukung oleh kondisi jaringan jalan yang mantap. Jaringan jalan yang kondisinya tidak mantap (kondisi rusak) ini pada umumnya di Kabupaten Cianjur terjadi pada ruas-ruas jalan kabupaten di kawasan pertanian yang berfungsi menghubungkan pusat-pusat produksi pertanian dengan lokasi pemasaran. Ruas-ruas jalan tersebut sebagaimana diperlihatkan pada Gambar 8 dan Gambar 9.

- Dengan masih rendahnya kualitas jaringan jalan pada kawasan pertaniaan tersebut, sehingga menyebabkan terhambatnya kelancaran distribusi produk hasil pertanian dan kehutanan ke daerah pemasaran. Hal ini berakibat kepada rendahnya tingkat produktifitas hasil pertanian dan kehutanan, yang pada akhirnya dapat mempengaruhi tingkat pertumbuhan PDRB dari sektor pertanian dan kehutanan di Kabupaten Cianjur.

- Berdasarkan data dari BPS Kabupaten Cianjur, laju pertumbuhan PDRB Kabupaten Cianjur dari sekor pertanian, kehutanan dan perikanan pada tahun 2015 adalah sebesar 2,09\% dan pada tahun 2016 sebesar 4,60\%. Laju pertumbuhan PDRB sektor ini tergolong masih rendah, sementara dari sektor perdagangan laju pertumbuhannya pada tahun 2015 sudah mencapai $6,45 \%$ dan pada tahun 2016 sebesar $4,55 \%$, serta dari sektor akomodasi dan makan minum pada tahun 2015 pertumbuhannya sudah mencapai $7,35 \%$ dan pada tahun 2016 mencapai sebesar $9,74 \%$.

- Apabila kondisi jaringan jalan di kawasan pertanian dan kehutanan dapat ditingkatkan kualitasnya, sehingga distribusi produk hasil pertanian dan kehutanan ke daerah pemasaran menjadi lebih lancar. Hal tersebut dapat memberi kontribusi terhadap peningkatan produktifitas hasil pertanian dan kehutanan, dan selanjutnya dapat memberi dukungan terhadap peningkatan laju pertumbuhan PDRB Kabupaten Cianjur dari sektor pertanian dan kehutanan.

- Zongzhang Li dan Xiaomin Liu (2009) dalam penelitiannya mengenai dampak dari pengembangan infrastruktur perdesaan terhadap efisiensi teknis produksi pertanian di negara Cina, menghasilkan suatu bentuk persamaan efisiensi teknis produksi pertanian dari hasil analisis regresi dengan menggunakan Tobit Model. Efisiensi teknis produksi pertanian tersebut dipengaruhi oleh lima variable independen infrastruktur perdesaan yang meliputi jalan, sekolah, listrik, telekomunikasi, dan suplai air. Hasil 
estimasi dari persamaan tersebut dengan efisiensi teknis sebagai variabel dependen sebagaimana diperlihatkan pada Tabel 8 berikut.

Tabel 8. Hasil Estimasi Variabel Infrastruktur Perdesaan Persamaan Efisiensi Teknis Tobit Model di Provinsi Negara Cina, Tahun 2006

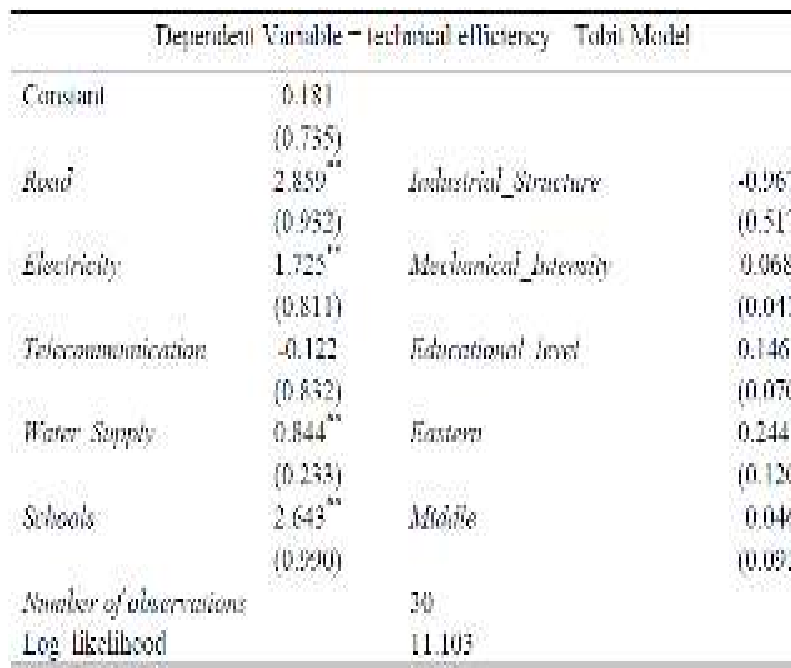

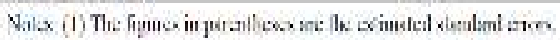

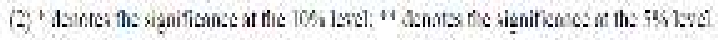

Sumber : Zongzhang Li dan Xiaomin Liu (2009)

- Menurut Zongzhang Li dan Xiaomin Liu (2009), jika proporsi kota-kota dengan jalan raya di atas kelas dua di daerah meningkat satu unit, maka efisiensi teknis produksi pertanian akan meningkat sebesar 2,859 unit.

- Dari penelitian yang telah dilakukan oleh Zongzhang Li dan Xiaomin Liu, terlihat bahwa kualitas jalan di daerah mempuyai pengaruh yang besar terhadap peningkatan produksi pertanian. Hal ini dapat dimengerti karena jalan mempunyai peran yang besar dalam melancarkan distribusi produksi pertanian ke daerah pemasaran.

- Apabila penelitian seperti yang dilakukan oleh Zongzhang Li dan Xiaomin Liu juga dapat dilakukan di Indonesia, maka dapat dihitung besarnya pengaruh kualitas jalan daerah terhadap efisiensi teknis produksi pertanian di Indonesia, yang selanjutnya dapat dihitung besarnya peningkatan pertumbuhan PDRB dari sektor pertanian.

\section{3 Analisis Efisiensi Anggaran Infrastruktur Jalan Terhadap Kualitas Jalan}

Sebagaimana telah dimaklumi, setiap tahun pemerintah daerah mengalokasikan anggaran untuk menjaga kualitas kondisi jalan daerah dengan jumlah alokasi anggaran bervariasi sesuai dengan panjang dan kondisi jalan di masing-masing daerah. Untuk mengetahui tingkat efisiensi alokasi anggaran infrastruktur jalan kabupaten di beberapa daerah kabupaten di Jawa Barat, dilakukan studi kasus terhadap 6 kabupaten di Jawa Barat berdasarkan alokasi anggaran infrastruktur jalan dan kualitas jalan pada tahun 2015 dengan menggunakan metode Data Envelopment Analysis (DEA).

Hasil analisis efisiensi korelasi alokasi anggaran infrastruktur jalan terhadap kualitas jalan (kondisi mantap) dengan metode DEA terhadap 6 kabupaten di Jawa Barat tersebut, sebagaimana diperlihatkan pada Tabel 9 sebagai berikut.

Tabel 9. Alokasi Anggaran Infrastruktur Jalan dan Efisiensi Capaian Kualitas Jalan

6 Kabupaten di Jawa Barat

\begin{tabular}{|clccccc}
\hline No. & KABUPATEN & $\begin{array}{c}\text { ANGGARAN } \\
\text { INFRASTRUKT } \\
\text { UR JALAN }\end{array}$ & $\begin{array}{c}\text { KUALITA } \\
\text { S JALAN }\end{array}$ & $\begin{array}{c}\text { TARGET } \\
\text { KUALITAS } \\
\text { JALAN }\end{array}$ & EFISIENSI & INEFISIENSI \\
\hline 1 & Cianjur & Rp. 92 miliar & $35,88 \%$ & $43,78 \%$ & $78,00 \%$ & $22,00 \%$ \\
\hline 2 & Majalengka & Rp. 283 miliar & $80,82 \%$ & $81,87 \%$ & $98,80 \%$ & $1,20 \%$ \\
\hline 3 & Bandung & Rp. 270 miliar & $76,30 \%$ & $76,30 \%$ & $100,00 \%$ & $0,00 \%$ \\
\hline 4 & Sumedang & Rp. 197 miliar & $63,08 \%$ & $70,49 \%$ & $88,30 \%$ & $11,70 \%$ \\
\hline 5 & Bandung Barat & Rp. 165 miliar & $65,16 \%$ & $83,69 \%$ & $71,60 \%$ & $28,40 \%$ \\
\hline 6 & Garut & Rp. 257 miliar & $90,20 \%$ & $100,00 \%$ & $80,50 \%$ & $19,50 \%$ \\
\hline
\end{tabular}

Sumber : Hasil Analisis Menggunakan Metode DEA 
Dari hasil analisis pada Tabel 9 tersebut di atas, dibuat grafik efisiensi anggaran infrastruktur jalan terhadap kualitas jalan dan garis kecenderungan (trend line) target kualitas jalan kabupaten yang efisien terhadap alokasi anggaran infrastruktur jalan, yang disebut dengan garis efisien (efficient frontier), sebagaimana diperlihatkan pada Gambar 12 berikut. Berdasarkan teori DEA, alokasi anggaran infrastruktur jalan mencapai skala efisiensi apabila kualitas jalan yang dicapai (persentase kondisi jalan mantap) berada pada garis efisien.

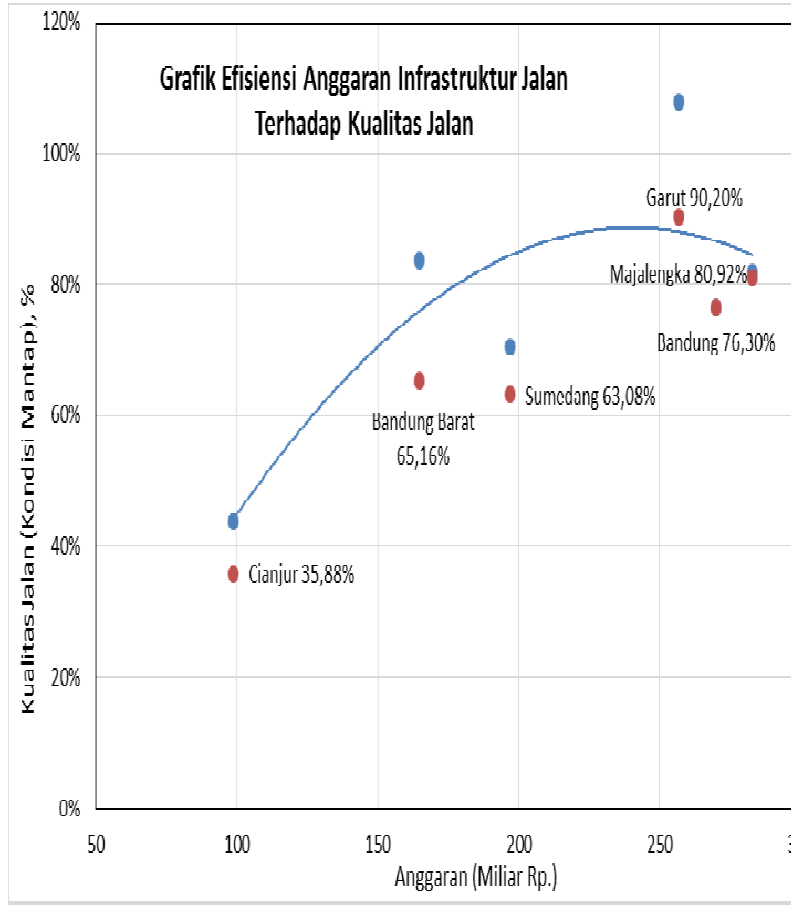

Gambar 12. Grafik Efisiensi Alokasi
Anggaran Infrastruktur Jalan
Terhadap Kualitas Jalan 6
Kabupaten Di Jawa Barat
Tahun 2015

Dari Gambar 12 tersebut, dapat dijelaskan sebagai berikut :

- Kualitas kondisi jalan Kabupaten Garut berada di atas garis kurva kualitas jalan kabupaten yang efisien (efficient frontier). Dapat dikatakan alokasi anggaran untuk infrastruktur jalan Kabupaten Garut telah mencapai sekala efisiensi. Sehingga tidak diperlukan adanya peningkatan atau penambahan alokasi anggaran untuk infrastruktur jalan Kabupaten Garut.

- Untuk Kabupaten Majalengka, kualitas kondisi jalan yang dicapai mendekati garis kurva kualitas jalan kabupaten yang efisien. Sehingga dapat dikatakan alokasi anggaran infrastruktur jalannya sudah mendekati skala efisiensi.

- Untuk Kabupaten Cianjur, Kabupaten Bandung Barat, Kabupaten Sumedang, dan Kabupaten Bandung, kualitas kondisi jalan berada di bawah garis kurva kualitas jalan kabupaten yang efisien. Ini berarti kualitas kondisi jalan yang dicapai pada saat ini berdasarkan besarnya anggaran yang dialokasikan belum mencapai skala efisiensi.

Untuk membahas lebih lanjut terhadap kualitas kondisi jalan Kabupaten Cianjur, dapat dilihat dari besaran alokasi anggaran infrastruktur jalan yang telah dialokasikan. Kabupaten Cianjur telah mengalokasikan anggaran infrastruktur jalan kabupaten pada tahun 2015 sebesar Rp. 99 miliar. Alokasi anggaran ini relatif lebih rendah dibandingkan 5 kabupaten lainnya yang ada di Jawa Barat. Dengan capaian kondisi jalan mantap pada tahun 2015 sebesar $35,88 \%$, alokasi anggaran penanganan jalan tersebut belum dikatakan mencapai skala efisiensi. Hal ini sesuai dengan hasil analisis efisiensi dengan metode DEA sebagaimana diperlihatkan pada Tabel 8 tersebut di atas. Tingkat efisiensi alokasi anggaran infrastruktur jalan dengan capaian kondisi jalan mantap sebesar $35,88 \%$ adalah sebesar $78,00 \%$ atau terjadi inefisiensi alokasi anggaran infrastruktur jalan pada tahun 2015 sebesar 22,00\%. Alokasi anggaran infrastruktur jalan Kabupaten Cianjur sebesar Rp. 99 miliar tersebut, mencapai skala efisiensi relatif terhadap 5 kabupaten lainnya, apabila persentase kondisi jalan mantap mencapai target kualitas jalan mantap, yaitu sebesar 43,78\%. Dimana persentase kondisi jalan mantap tersebut berada pada garis kurva kualitas jalan yang efisien (efficient frontier) sebagaimana diperlihatkan pada Gambar 12.

Untuk mengetahui penyebab terjadinya inefisiensi alokasi anggaran infrastruktur jalan Kabupaten Cianjur, perlu dilakukan evaluasi terhadap capaian kondisi mantap jalan kabupaten dari hasil pelaksanaan programprogram kegiatan penanganan jalan yang telah dilaksanakan selama beberapa tahun belakangan ini. Dengan diketahui penyebab terjadinya inefisiensi alokasi anggaran infrastruktur jalan tersebut, sehingga dapat 
dijadikan sebagai dasar untuk melakukan perubahan terhadap alokasi anggaran infrastruktur jalan Kabupaten Cianjur pada tahun-tahun yang akan datang, agar alokasi anggaran tersebut dapat mencapai skala efisiensi.

Untuk dapat meningkatkan kualitas jalan (kondisi mantap) setiap tahunnya perlu dilakukan hal-hal sebagaimana berikut :

1. Mempertahankan kondisi jalan mantap yang sudah dicapai pada tahun sebelumnya dengan cara melaksanakan pemeliharaan rutin pada seluruh ruas-ruas jalan yang dalam kondisi mantap sesuai dengan umur pelayanannya.

2. Melaksanakan periodik/rehabilitasi pemeliharaan untuk memperpanjang umur pelayanan jalan mantap yang hampir habis umur pelayanannya, yaitu untuk kondisi jalan yang mengalami rusak sedang sampai mendekati rusak.

3. Melaksanakan pembangunan/peningkatan jalan yang mengalami rusak berat untuk menambah panjang ruas jalan dalam kondisi mantap.

Adapun jenis program/kegiatan penanganan jalan, besarnya alokasi anggaran penanganan jalan, dan capaian kualitas (kondisi mantap) jalan Kabupaten Cianjur, serta tingkat efisiensi anggaran dari tahun 2015 sampai 2016 sebagaimana diperlihatkan pada Tabel 10 berikut.

Tabel 10. Program/Kegiatan Penanganan Jalan, Alokasi Anggaran, dan Capaian Kondisi Jalan Mantap Kabupaten Cianjur, serta Tingkat Efisiensi Anggaran Tahun 2015 - 2016

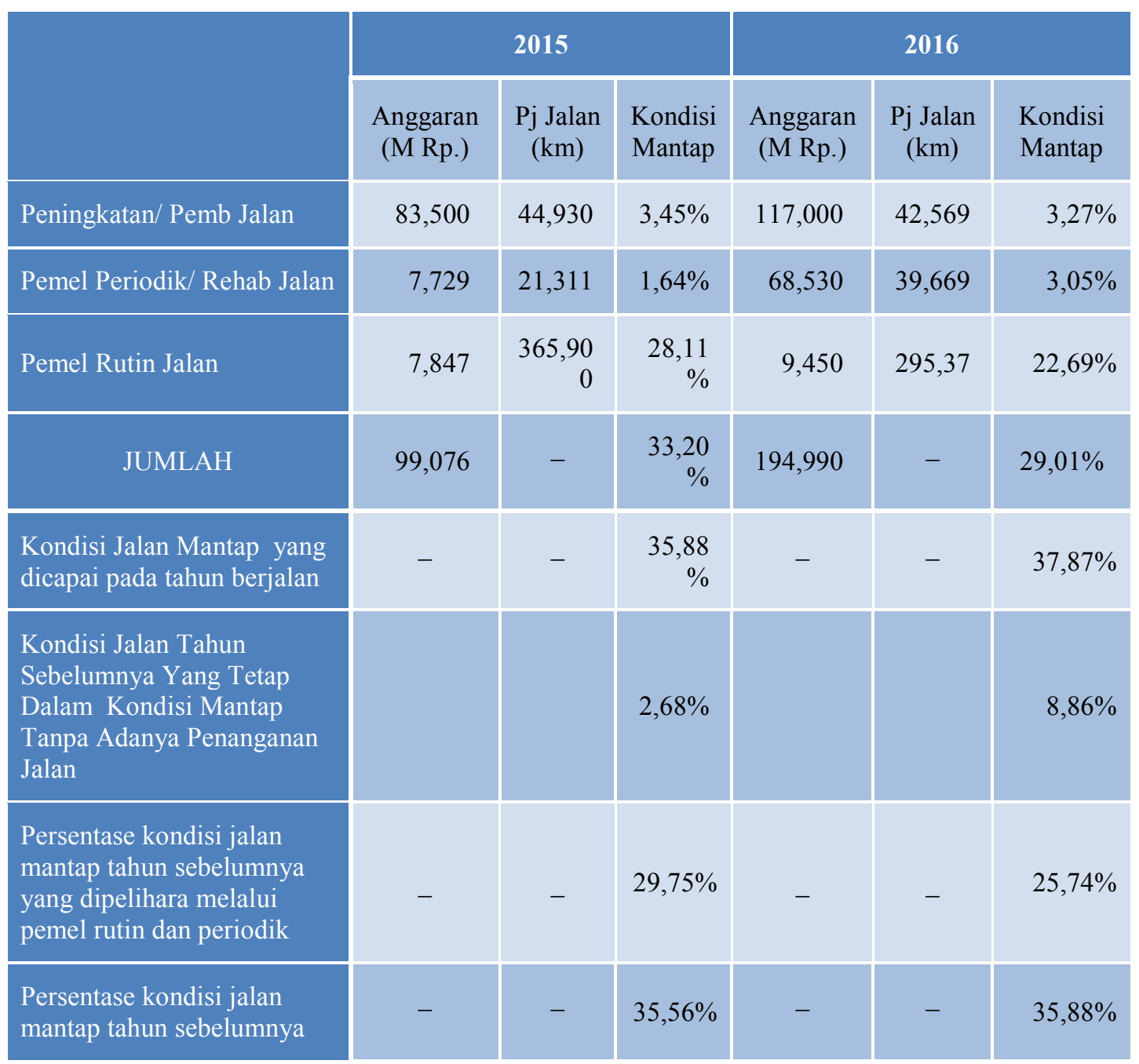




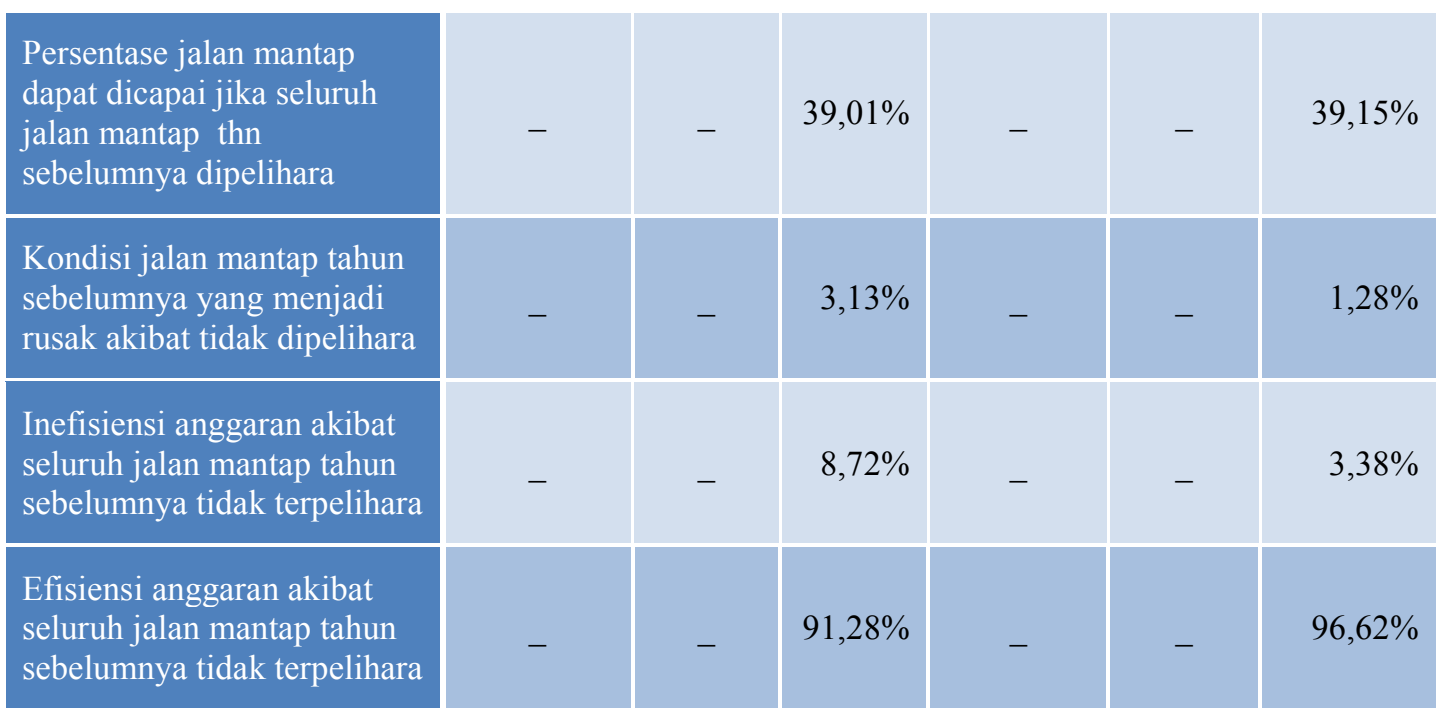

Sumber :Hasil analisis data dari Dinas PUPR Kab. Cianjur

Dari Tabel 10 tersebut di atas dapat dilihat, kondisi jalan mantap kabupaten pada tahun 2015 sebesar 35,88\% diperoleh dari:

1. Kegiatan pembangunan/peningkatan jalan dengan alokasi anggaran sebesar $\mathrm{Rp}$. 83,500 miliar, menghasilkan panjang penanganan jalan sepanjang $44,930 \mathrm{~km}$. Kegiatan ini menambah persentase kondisi jalan mantap sebesar 3,45\%;

2. Kegiatan pemeliharaan periodik/rehabilitasi jalan dengan alokasi anggaran sebesar Rp. 7,729 miliar, dengan panjang penanganan jalan sepanjang 21,311 km. Kegiatan ini memperpanjang umur pelayanan jalan, sehingga jalan tidak menjadi rusak dan tetap berada dalam kondisi mantap sebesar $1,64 \%$;

3. Kegiatan pemeliharaan rutin jalan dengan alokasi anggaran sebesar Rp. 7,847 miliar. Kegiatan ini untuk menjaga agar jalan tetap dalam kondisi mantap sepanjang $365,900 \mathrm{~km}$, sehingga jalan tetap terjaga dalam kondisi mantap sebesar $28,11 \%$.

4. Kondisi jalan mantap pada tahun 2014 yang tidak mendapat penanganan pemeliharaan tetapi masih tetap dapat bertahan dalam kondisi mantap pada tahun 2015 sebesar 2,68\%.

Dari kondisi jalan mantap pada tahun 2014 sebesar 35,56\%, yang dapat dipertahankan kondisinya melalui kegiatan pemeliharaan rutin dan pemeliharaan periodik/rehabilitasi jalan pada tahun 2015 adalah sebesar $29,75 \%$, yaitu diperoleh dari pemeliharaan periodik sebesar $1,64 \%$ dan pemeliharaan rutin sebesar $28,11 \%$. Seharusnya seluruh jalan mantap pada tahun 2014 tersebut mendapat penanganan peliharaan rutin atau periodik, agar kondisi jalan mantap yang telah dicapai pada tahun 2014 tersebut dapat dipertahankan pada tahun 2015.

Seandainya apabila seluruh jalan mantap tahun 2014 sebesar 35,56\% tersebut mendapat pemeliharaan rutin maupun pemeliharaan periodik/rehabilitasi pada tahun 2015, maka jalan mantap yang dihasilkan pada tahun 2015 dapat mencapai sebesar 39,01\%. Angka ini diperoleh dari kondisi jalan mantap tahun 2014 yang dapat dipertahankan kondisinya pada tahun 2015, ditambah dengan kondisi jalan mantap hasil dari kegiatan pembangunan/ peningkatan jalan tahun 2015 sebesar 3,45\%.

Dengan tidak dilaksanakannya pemeliharaan seluruh ruas jalan mantap tahun 2014 pada tahun 2015, akibatnya terjadi penurunan kondisi jalan mantap yang dicapai pada tahun 2014 menjadi tidak mantap (turun menjadi rusak) pada tahun 2015 sebesar $3,13 \%$. Penurunan kondisi mantap menjadi rusak ini didapat dari selisih dari persentase kondisi jalan mantap yang seharusnya dapat dicapai sebesar 39,01\% dengan kondisi jalan mantap yang dicapai sebesar $35,88 \%$ pada tahun 2015.

Dengan turunnya kondisi jalan mantap tahun 2014 sebesar 3,13\% tersebut pada tahun 
2015, terjadi inefisiensi alokasi anggaran infrastruktur jalan sebesar $8,72 \%$, yaitu merupakan persentase jalan mantap yang turun kondisinya menjadi rusak terhadap kondisi jalan mantap yang dicapai pada tahun 2015, atau efisiensi alokasi anggaran infrastruktur jalan yang terjadi pada tahun 2015 mencapai sebesar $91,28 \%$.

Demikian juga halnya yang terjadi pada tahun 2016. Akibat tidak seluruh ruas jalan dalam kondisi mantap yang dicapai pada tahun 2015 mendapat penanganan pemeliharaan baik rutin maupun periodik/rehabilitasi pada tahun 2016, sehingga terjadi penurunan kondisi jalan mantap tahun 2015 menjadi rusak pada tahun 2016 sebesar $1,28 \%$. Yaitu merupakan selisih dari persentase kondisi jalan mantap yang seharusnya dapat dicapai sebesar 39,15\% dengan kondisi jalan mantap yang dicapai sebesar $37,87 \%$ pada tahun 2016 .

Dengan demikian akibat dari penurunan kondisi jalan mantap sebesar 1,28\% tersebut pada tahun 2016, terjadi inefisiensi alokasi anggaran infrastruktur jalan sebesar $3,38 \%$. Yaitu merupakan persentase jalan mantap yang turun kondisinya menjadi rusak terhadap kondisi jalan mantap yang dicapai pada tahun 2016, atau efisiensi alokasi anggaran infrastruktur jalan yang terjadi pada tahun 2016 mencapai sebesar 96,62\%.

Dari hasil evaluasi terhadap capaian kondisi mantap jalan Kabupaten Cianjur tahun 2015 dan tahun 2016, dapat diketahui inefisiensi alokasi anggaran infrastruktur jalan Kabupaten Cianjur pada tahun 2015 adalah sebesar 8,72\%, dan pada tahun 2016 sebesar $3,38 \%$. Akibat inefisiensi dari pengalokasian anggaran infrastruktur jalan tersebut, sehingga berdampak terhadap rendahnya capaian kondisi mantap jalan Kabupaten Cianjur pada tahun 2015 dan tahun 2016.

Sebagaimana telah diamanatkan dalam Pasal 30 ayat (1) huruf $b$ Undang-undang Nomor 38 Tahun 2004 tentang Jalan, bahwa Penyelenggara jalan wajib memprioritaskan pemeliharaan, perawatan dan pemeriksaan jalan secara berkala untuk mempertahankan tingkat pelayanan jalan sesuai dengan standar pelayanan minimal yang ditetapkan. Kemudian di dalam Pasal 97 ayat (2) Peraturan Pemerintah Nomor 34 Tahun 2006 Tentang
Jalan juga ditegaskan bahwa pemeliharaan jalan merupakan prioritas tertinggi dari semua jenis penanganan jalan. Yang mana pada ayat (3) Peraturan Pemerintah tersebut dijelaskan pemeliharaan jalan meliputi pemeliharaan rutin, pemeliharaan berkala (periodik), dan rehabilitasi jalan.

Selain kondisi jalan dipengaruh oleh besarnya alokasi anggaran penanganan jalan, faktor-faktor lain yang menyebabkan rendahnya kualitas jalan Kabupaten Cianjur diantaranya adalah:

- Tidak terpeliharanya jalan dengan baik akibat pelaksanaan pemeliharaan jalan dilaksanakan tidak sesuai prosedur, sehingga kualitas hasil pelaksanaan pemeliharaan menjadi kurang baik. Hal ini diketahui dari hasil monitoring terhadap pelaksanaan pekerjaan pemeliharaan jalan. Dimana pelaksanaan pekerjaan pemeliharaan jalan dikerjakan tanpa mengikuti prosedur sebagaimana mestinya, karena kurangnya tingkat kepedulian dan rasa tanggungjawab para pekerja pemelihara jalan terhadap hasil pelaksanaan pekerjaannya .

- Pelaksanaan pembangunan/peningkatan jalan kualitasnya rendah.

Hal ini disebabkan lemahnya pengawasan oleh aparatur Dinas Pekerjaan Umum dan Penataan Ruang Kabupaten Cianjur terhadap pelaksanaan pekerjaan jalan yang dilakukan oleh Pihak Penyedia Jasa.

- Keterbatasan kemampuan SDM aparatur Dinas Pekerjaan Umun dan Penataan Ruang Kabupaten Cianjur dalam penyelenggaraan pemeliharaan jalan.

Kurangnya pengetahun para pekerja jalan dan aparatur yang bertanggungjawab terhadap pelaksanaan pemeliharaan jalan menyebabkan hasil pelaksanaan pekerjaan pemeliharaan jalan kurang memenuhi standar teknis. Hal ini dikarenakan dari 11 Balai Pemeliharaan Jalan yang dimiliki Dinas Pekerjaan Umum dan Penataan Ruang Kabupaten Cianjur, mulai dari pejabat struktural sampai ke petugas pemelihara jalan, tidak ada satupun yang memiliki latar belakang pendidikan di bidang pekerjaan jalan, sebagaimana diperlihatkan pada Tabel 11 berikut. 
Tabel 11. Jumlah Aparatur Pada Balai Pemeliharaan Jalan Kabupaten Cianjur dan Tingkat Pendidikannya

\begin{tabular}{|c|c|c|c|c|c|}
\hline \multirow[b]{2}{*}{ JABATAN } & \multicolumn{4}{|c|}{ TINGKAT PENDIDIKAN } & \multirow[b]{2}{*}{ JUMLAH } \\
\hline & $\begin{array}{c}\text { S1/S2 } \\
\text { Non T } \\
\text { Sipil }\end{array}$ & SMA/STM & SMP & $\mathrm{SD}$ & \\
\hline Kepala Balai & 9 org & 2 org & - & - & 11 org \\
\hline Ka Subag TU & 7 org & 4 org & - & - & 11 org \\
\hline $\begin{array}{l}\text { Pengawas dan } \\
\text { Pemelihara Jalan }\end{array}$ & 6 org & 82 org & 25 org & 20 org & 133 org \\
\hline $\begin{array}{l}\text { JUMLAH } \\
\text { APARATUR }\end{array}$ & 22 org & 88 org & 25 org & 20 org & 155 org \\
\hline
\end{tabular}

Sumber : Subag Bagian Umum dan Kepegawairan DinasPUPR Kab. Cianjur

- Penentuan pelaksanaan program pemeliharaan jalan tidak berdasarkan penilaian yang objektif.

Penentuan ruas-ruas jalan yang mendapat penanganan pemeliharaan jalan tidak mengikuti prosedur sebagaimana diatur dalam Surat Keputusan Dirjen Bina Marga No. 77/KPTS/Db/1990 Tentang Petunjuk Teknis Perencanaan dan Penyusunan Program Jalan Kabupaten, melaikan berdasarkan penilaian subjektif. Hal ini dikarenakan kurangnya pengetahuan para aparatur pengelola program pemeliharaan jalan, akibat seringnya terjadi pergantian personil baru yang tidak memiliki pengetahuan mengenai prosedur program pemeliharaan jalan.

- Terjadinya kelebihan muatan kendaraan (exessive over loading) yang menyebabkan terjadinya kerusakan jalan secara dini sebelum umur teknis jalan tercapai.

Hal ini disebabkan karena tidak tersedianya jembatan timbang sebagai alat ukur untuk mengendalikan kelebihan muatan kendaraan pada ruas-ruas jalan kabupaten.

- Sering terjadi kerusakan jalan pada daerah-daerah rawan bencana.

Di beberapa kolaksi di wilayah bagian tengah dan selatan Kabupaten Cianjur sering terjadi bencana alam akibat pergerakan tanah. Hal ini menyebabkan sering terjadinya kerusakan jalan akibat dari pergerakan tanah tersebut.

\section{BAB V KESIMPULAN DAN REKOMENDASI}

\section{1 Kesimpulan}

1. Dari hasil analisis efisiensi dengan menggunakan metode Data Envelopment Analysis (DEA) terhadap kondisi jalan kabupaten dan pertumbuhan ekonomi daerah Kabupaten Cianjur dan 5 kabupaten lainnya di Jawa Barat, menunjukkan bahwa kualitas jalan (kondisi mantap) 6 kabupaten di Jawa Barat tersebut pada tahun 2015 semuanya belum mencapai skala efisiensi untuk mendukung pertumbuhan ekonomi di setiap kabupaten.

2. Kondisi jalan mantap Kabupaten Cianjur belum mendukung terhadap pertumbuhan ekonomi Kabupaten Cianjur. Hal tersebut dikarenakan rendahnya kualitas jaringan jalan akses menuju ke pusat-pusat produksi pertanian dan kehutanan, dimana sektor pertanian dan kehutanan tersebut merupakan penyumbang terbesar PDRB Kabupaten Cianjur, yaitu sebesar 34,09\% pada tahun 2015. Rendahnya kualitas jalan akses menuju ke pusat-pusat produksi pertanian dan kehutanan ini menyebabkan distribusi hasil produksi pertanian dan kehutanan ke daerah 
pemasaran menjadi terhambat. Sehingga hal tertsebut berakibat kepada rendahnya tingkat produktifitas hasil pertanian dan kehutanan, yang kemudian berdampak terhadap tingkat pertumbuhan ekonomi Kabupaten Cianjur dari sektor lapangan usaha pertanian dan kehutanan. Kualitas jaringan jalan akses menuju ke pusatpusat produksi pertanian dan kehutanan tersebut seharusnya dalam kondisi mantap, agar dapat mendukung terhadap pertumbuhan ekonomi Kabupaten Cianjur dari sektor lapangan usaha pertanian dan kehutanan.

3. Kualitas jaringan jalan Kabupaten Cianjur dalam kondisi mantap pada umumnya berada di kawasan perkotaan dan di kawasan wisata, dimana sektor-sektor lapangan usaha seperti penyediaan akomodasi (perhotelan), perdagangan besar dan eceran, pada umumnya terkonsentrasi pada ruas jalan tersebut. Namun sektor-sektor lapangan usaha tersebut kontribusinya cukup kecil terhadap pertumbuhan ekonomi Kabupaten Cianjur. Akomodasi dan perhotelan hanya mempunyai kontribusi terhadap PDRB sebesar 5,9\%, sedangkan Sektor perdagangan besar dan eceran, hanya berkontribusi sebesar $18,46 \%$ pada tahun 2015. Kondisi jalan mantap yang mendukung sektor-sektor tersebut tidak mendukung terhadap peningkatan pertumbuhan ekonomi Kabupaten Cianjur secara signifikan.

4. Dari hasil analisis efisiensi dengan menggunakan metode DEA terhadap alokasi anggaran infrastruktur jalan dan kondisi jalan kabupaten terhadap 6 kabupaten di Jawa Barat, menunjukkan alokasi anggaran infrastruktur jalan pada tahun 2015 untuk Kabupaten Garut telah mencapai skala efisiensi, dan Kabupaten Majalengka mendekati skala efisiensi. Sedangkan untuk Kabupaten Cianjur, Kabupaten Bandung, Kabupaten Bandung Barat, dan Kabupaten Sumedang belum mencapai skala efisiensi untuk meningkatkan kualitas jalan.

5. Dari hasil evaluasi terhadap capaian kondisi jalan mantap Kabupaten Cianjur tahun 2015 dan tahun 2016, diketahui inefisiensi alokasi anggaran infrastruktur jalan terjadi karena tidak seluruh ruas jalan kabupaten yang sudah dalam kondisi mantap mendapat alokasi anggaran pemeliharaan jalan. Akibatnya sebagian ruas jalan kondisi mantap yang tidak dipelihara turun kondisinya menjadi rusak. Pada tahun 2015 terjadi penurunan kondisi jalan mantap menjadi rusak sebesar 3,13\% dan pada tahun 2016 penurunannya sebesar $1,28 \%$.

6. Selain daripada faktor alokasi anggaran pemeliharaan jalan, faktor-faktor lain yang dapat menyebabkan terjadinya inefisiensi anggaran infrastruktur jalan di Kabupaten Cianjur, diantaranya :

- Tidak terpeliharanya jalan dengan baik akibat tidak cukupnya alokasi anggaran untuk pemeliharaan jalan, sehingga menyebabkan kualitas hasil pekerjaan pemeliharaan rendah;

- Pelaksanaan pemeliharaan jalan tidak dilakukan sesuai dengan prosedur;

- Keterbatasan kemampuan SDM aparatur Dinas Pekerjaan Umum dan Penataan Ruang dalam penyelenggaraan pemeliharaan jalan;

- Penentuan pelaksanaan program pemeliharaan jalan tidak berdasarkan penilaian yang objektif;

- Kelebihan muatan kendaraan (exessive over loading) yang menyebabkan terjadinya kerusakan jalan secara dini sebelum umur teknis jalan tercapai;

- Kerusakan jalan terjadi pada daerah - daerah rawan bencana alam. 


\section{DAFTAR PUSTAKA}

Adisasmita, H. Rahardjo. 2005. Dasa-dasar Ekonomi Wilayah. Yogyakarta: Graha Ilmu.

Badan Pusat Statistik. 2017. Kabupaten Bandung Dalam Angka 2017. Bandung: BPS Kabupaten Bandung.

2017. Kabupaten Bandung Barat Dalam Angka 2017. Bandung Barat: BPS Kabupaten Bandung Barat.

2017. Kabupaten Bekasi Dalam Angka 2017. Bekasi: BPS Kabupaten Bekasi.

2017. Kabupaten Bogor Dalam Angka 2017. Cibinong: BPS Kabupaten Bogor.

2017. Kabupaten Ciamis Dalam Angka 2017. Ciamis: BPS Kabupaten Ciamis.

2017. Kabupaten Cianjur Dalam Angka 2017. Cianjur: BPS Kabupaten Cianjur.

2017. Kabupaten Garut Dalam Angka 2017. Garut: BPS Kabupaten Garut.

2017. Kabupaten Indramayu Dalam Angka 2017. Indramayu: BPS Kabupaten Indramayu.

2017. Kabupaten Kuningan Dalam Angka 2017. Kuningan: BPS Kab. Kuningan.

2017. Kabupaten Majalengka Dalam Angka 2017. Majalengka: BPS Kabupaten Majalengka.

2017. Kabupaten Purwakarta Dalam Angka 2017. Purwakarta: BPS Kabupaten Purwakarta.

2017. Kabupaten Subang Dalam Angka 2017. Subang: BPS Kabupaten Subang.

2017. Kabupaten Sukabumi Dalam Angka 2017. Sukabumi: BPS Kab. Sukabumi.
2017. Kabupaten Sumedang Dalam Angka 2017. Sumedang: BPS Kabupaten Sumedang.

Cooper, W.W., Seiford, L.M. and Zhu, Joe. (2011) Data Envelopment Analysis: History, Models, and Interpretation.

https://www.researchgate.net/publ ication/ 226038831. Diakses 25 Agustus 2018.

Ditjen Bina Marga. 1990. Surat Keputusan Direktur Jendral Bina Marga Nomor 77/KPTS/Db/1990 Tentang Petunjuk Teknis Perencanaan dan Penyusunan Program Jalan Kabupaten. Jakarta: Ditjen Bina Marga.

Hasim, Indayani. 2013. Analisis Keterkaitan Transportasi Darat Dengan Pertumbuhan Ekonomi di Kabupaten Merauke Periode 2002 - 2011. Makassar.

International Labour Organization. 2004. Review of Rural Road Maintenance in Lao PDR: Current Status, Issues and Options.

https://www.ilo.org/wcmsp5/grou ps/ public/---asia/--ro.../wcms_107569.pdf. Diakses 9 November 2018.

Jean, Marc Huguenin. 2012. Data Envelopment Analysis (DEA) A pedagogical guide for decision makers in the public sector. Lausanne. IDHEAP.

Kementerian PUPR. 2015. Peraturan Menteri Pekerjaan umum dan Perumahan Rakyat Nomor 47/PRT/M/2015 Tentang Petunjuk Teknis Penggunaan Dana Alokasi Khusus Bidang Infrastruktur. Jakarta: Kementerian PUPR.

Li, Zongzhang and Liu, Xiaomin. 2009. The Effects of Rural Infrastructure Development on Agricultural Production Technical Efficiency: Evidence from the Data of Second National Agricultural Census of China.

http://ageconsearch.umn.edu/ 
bitstream/51028/2/Rural-

Infrastructure.pdf. Diakses 19

November 2018.

Maku, Nugroho. 2011. Analisis Determinasi Infrastruktur Jalan Terhadap Produk Regional Bruto (Studi Kasus di Provinsi Nusa Tenggara Timur). Makalah Seminar Nasional Aplikasi Teknologi Prasarana Wilayah. Surabaya.

Molinos, Maria and Encias, Pelipe. 2016. Benchmarking The Energy Performance Of Office Buildings: A Data Envelopment Analysis Approach. Santiago. Univ of Chile.

Pemerintah Daerah Kabupaten Cianjur. 2016. Rencana Pembangunan Jangka Menengah Daerah Kabupaten Cianjur Tahun 2016 - 2021. Cianjur.

Pemerintah Provinsi Jawa Barat. 2017. PDRB Kabupaten/Kota di Jawa Barat Atas Dasar Harga Berlaku Menurut Lapangan Usaha Tahun 2010 - 2016. Bandung: Pusdalitbang Provinsi Jawa Barat.

Pemerintah Republik Indonesia. 2004. Undang-undang Nomor 38 Tahun 2004 Tentang Jalan. Jakarta: Sekretariat Negara Republik Indonesia.

Pemerintah Republik Indonesia. 2006. Peraturan Pemerinta Nomor 34 Tahun 2006 Tentang Jalan. Jakarta: Sekretariat Negara Republik Indonesia.

Pemerintah Republik Indonesia. 2014. Undang-undang Nomor 23 Tahun 20014 Tentang Pemerintahan Daerah. Jakarta: Sekretariat Negara Republik Indonesia.

Sidik, Adi Pramono. 2011. Pengaruh Pembangunan Infrastruktur Jalan dan Listrik Terhadap Pertumbuhan Ekonomi di Kalimantan Tahun 1994 - 2008. Jakarta.

Tandung, Laen Sugi Rante. 2015. Analisis Pengaruh Infrastruktur Jalan
Terhadap Pertumbuhan Ekonomi Kabupaten Mamasa Periode 2003 - 2013. Makassar.

The United Republic Of Tanzania and JICA. 2014. Operational Guidelines for District Roads Maintenance. https://www.jica.go.jp/tanzania/en glish/activities/...att/guide lines_all.pdf. Diakses 9 November 2018.

Yong-bae Ji and Lee, Choon Joo. Data Envelopment Analysis in Stata. The Stata Journal (yyyy). Seoul. Korea National Defense University. 